WORKING PAPER

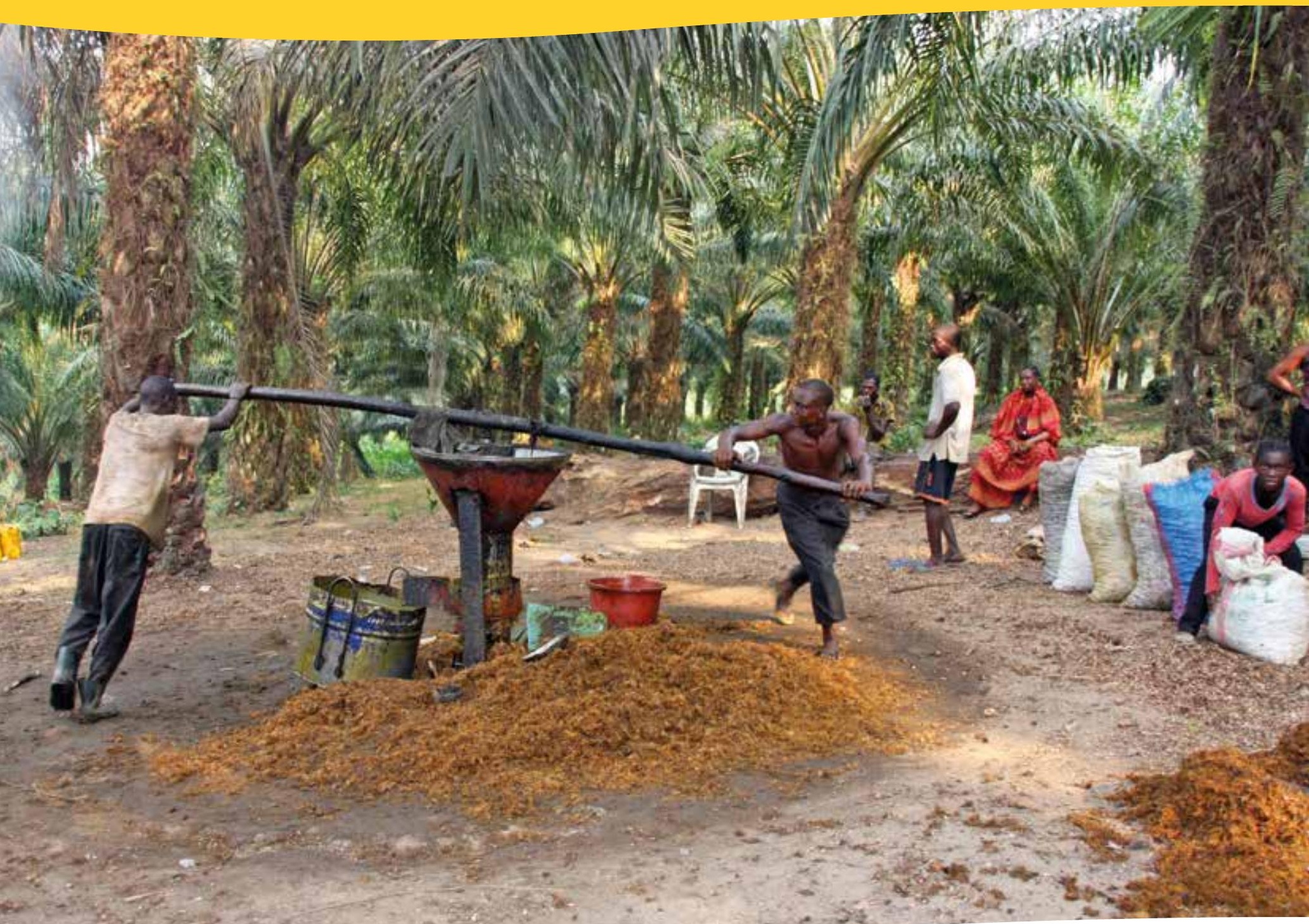

\title{
Artisanal Milling of Palm Oil in Cameroon
}

Yvonne K. Nchanji

Ofundem Tataw

Raymond N. Nkongho

Patrice Levang
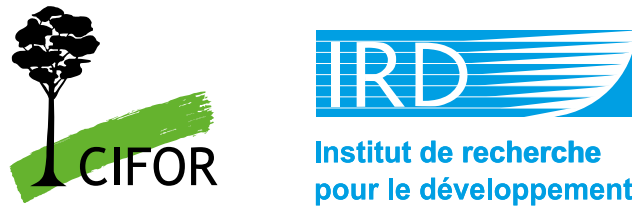



\title{
Artisanal Milling of Palm Oil in Cameroon
}

\author{
Yvonne K. Nchanji
}

Center for International Forestry Research (CIFOR)

\section{Ofundem Tataw}

Faculty of Science, University of Buea

\section{Raymond N. Nkongho}

Center for International Forestry Research (CIFOR)

\section{Patrice Levang}

Institut de Recherche pour le Développement (IRD)

Center for International Forestry Research (CIFOR) 
Working Paper 128

(c) 2013 Center for International Forestry Research

Content in this publication is licensed under a Creative Commons Attribution-NonCommercial-NoDerivs 3.0 Unported License http://creativecommons.org/licenses/by-nc-nd/3.0/

Nchanji Y. K., Tataw O, Nkongho R. N. and Levang P. 2013. Artisanal Milling of Palm Oil in Cameroon. Working Paper 128. Bogor, Indonesia: CIFOR.

Cover photo by Patrice Levang/IRD and CIFOR

Tournée-tournée manual palm oil press in Mbongo, Littoral Region

\section{CIFOR}

Jl. CIFOR, Situ Gede

Bogor Barat 16115

Indonesia

$\mathrm{T}+62(251) 8622-622$

$\mathrm{F}+62(251) 8622-100$

Ecifor@cgiar.org

\section{cifor.org}

We would like to thank all donors who supported this research through their contributions to the CGIAR Fund. For a list of Fund donors please see: https://www.cgiarfund.org/FundDonors

Any views expressed in this book are those of the authors. They do not necessarily represent the views of CIFOR, the editors, the authors' institutions, the financial sponsors or the reviewers. 


\section{Contents}

List of Figures, Pictures and Tables iv

Abbreviations

Acknowledgments $\quad$ v

Introduction

1. Materials and methods 1

2. Results and discussion $\quad 3$

2.1 Small-scale artisanal milling 3

2.2 Processing of fresh fruit bunches (FFBs) into red oil 3

2.3 The production of kernel oil and soap $\quad 16$

2.4 Commercialization of CPO 17

2.5 Contribution of income to household livelihood 19

2.6 The role of women $\quad 19$

2.7 Constraints in small scale/artisanal milling of red palm oil $\quad 19$

$\begin{array}{lll}2.8 \text { Oil storage } & 20\end{array}$

$\begin{array}{ll}\text { 3. Conclusion and recommendations } & 21\end{array}$

4. References 22 


\section{List of Figures, Pictures and Tables}

\section{Figures}

1. Map of Cameroon showing study locations 1

2. Schematic representation of milling activities 8

3. Contribution of family and hired labor 14

4. Average cost of first and second grades of oil supplied to tertiary buyers (in 20L) 18

\section{Pictures}

1. Manual vertical press

2. Motorized horizontal press

3. Combined motorized hydraulic machine and press system 7

4. Semi-automated press (side view) 7

5. Semi-automated press (side view) 7

6. In-built metallic drums for CPO clarification 7

7. Chopped or shredded FFBs 9

8. Halves of cut FFBs 9

9. Sieving of palm fruits $\quad 10$

10. Crushed material emptied into metallic cage 11

11. Crushed material pressed to extract RPO using hydraulic press 11

12. RPO directed into well built-in hole 11

13. RPO filled into containers -12

$\begin{array}{ll}\text { 14. Fiber-kernel separator } & 16\end{array}$

15. Loaded bags of palm kernel 16

16. Local soap produced from palm oil. 17

17. Palm oil retailer 17

\section{Tables}

1. Distribution of respondents in the study areas. 4

2. Distribution of respondents by type of service provider/processor. 5

3. Type of processing equipment used 6

4. Average production efficiency of different types of presses 13

5. Relative extraction efficiency (\%) per ton of FFB during the peak and
low seasons in the area

6. Average labor cost per activity in the processing of 1 ton of FFB 15

7. Fluctuation in prices of CPO in local markets 18

8. Contribution of income (from sales of CPO) to household livelihood in the study areas 


\section{Abbreviations}

$\begin{array}{ll}\text { CIFOR } & \text { Centre for International Forestry Research } \\ \text { CIG } & \text { Common initiative group } \\ \text { CPO } & \text { Crude palm oil } \\ \text { CR } & \text { Centre region } \\ \text { DO } & \text { Divisional officer } \\ \text { DTP } & \text { Dura, tenera and pisifera } \\ \text { EFB } & \text { Empty fruit bunch } \\ \text { FAO } & \text { Food and Agriculture Organization of the United Nations } \\ \text { FCFA } & \text { Franc de la Communauté Financière Africaine } \\ \text { FFA } & \text { Free fatty acid } \\ \text { FFB } & \text { Fresh fruit bunch } \\ \text { HP } & \text { Hydraulic press } \\ \text { Ha } & \text { Hectare } \\ \text { LR } & \text { Littoral Region } \\ \text { MINADER } & \text { Ministry of Agriculture and Rural Development } \\ \text { MINEPIA } & \text { Ministry of Fisheries, Animal Industries and Veterinary Medicine } \\ \text { MINFOF } & \text { Ministry of Forestry and Wildlife } \\ \text { NGO } & \text { Non Governmental Organization } \\ \text { OPP } & \text { Oil palm plantation } \\ \text { PAMOL } & \text { Pamol Plantations limited } \\ \text { POM } & \text { Palm oil mill } \\ \text { POP } & \text { Palm oil processing } \\ \text { PV } & \text { Plantations villageoises (small- and medium-sized holdings) } \\ \text { SDO } & \text { Senior Divisional Officer } \\ \text { SGSOC } & \text { Sithe Global Sustainable Oils Cameroon } \\ \text { SH } & \text { Smallholder } \\ \end{array}$

\section{Acknowledgments}

The authors want to thank all planters, millers and traders who devoted their time to answer our questions. Special thanks to Mr. Emmanuel Ngom for his comments and suggestions on earlier versions of this report. 


\section{Introduction}

The oil palm (Eleis guineensis Jacq.) is a perennial tree crop of the Arecaceae family (Rieger 2012). It is native to the countries bordering the Gulf of Guinea (Hoyle and Levang 2012), with the main belts running through the southern latitudes of Cameroon, Ivory Coast, Ghana, Liberia, Nigeria, Sierra Leone and into the equatorial region of Angola and Congo (Bakoume and Mahbob 2006; Carrere 2006). In the wild, the oil palm fruit occurs in two forms, termed dura (with a large kernel) and pisifera (having no shell and yet sterile). Tenera is a hybrid from dura and pisifera, and the most cultivated variety because it produces fruits with higher oil content (Rieger 2012). It is the preferred commercial variety cultivated by agro-industries in Cameroon and smallholders close to the agro-industrial areas (Hoyle and Levang 2012).

Processing oil-palm fruits for edible oil has been practised in Africa for thousands of years, and the highly colored and flavored oil produced is an essential ingredient in much of traditional West African cuisine. This crop is versatile and its products [such as palm oil, sauces, soap, wine, fertilizer (ashes), roofing (leaves), building material (trunk), medicines (roots)] are of great economic value in West and Central Africa (Carrere 2010; Ibitoye et al. 2011). For centuries, oil palm has provided local communities with a large number of benefits. Its primary purpose until now has been the extraction of palm oil (from the flesh of the oil palm fruit) and palm kernel oil (from its kernel or seed) for the production of edible and industrial oils (Carrere 2006). Palm kernel waste (after the oil has been extracted) is also used as animal feed and in co-firing in electricity generation. The palm oil industry is worth at least USD 20 billion annually (Hoyle and Levang 2012).

The production of palm oil can be grouped into traditional (artisanal) and industrial milling (Carrere 2010). Modern processing of oil-palm fruit bunches into edible oil (CPO) may be categorized into traditional methods, small-scale mechanical units, medium-scale mills and large industrial mills depending on the degree of complexity. In Cameroon, the production is stratified in three sectors: an agro-industrial sector, smallholders ( $\mathrm{SH})$ in contract with agro-industries and a traditional independent artisanal sector (Bakoume et al. 2002). The traditional process is simple, but tedious and rather inefficient.

Red or Crude palm oil (CPO) is an important source of vitamin A (Atinmo and Bakre 2003) obtained from the transformation of loose palm nuts. The process entails activities that provide many job opportunities to rural people at different levels (skilled and unskilled, formal and informal). This helps in income generation and poverty reduction in the rural setting. The women are involved in different stages of production and commercialization of CPO to assist in the upkeep of their families (Ibeckwe 2008).

Cameroon is ranked the world's 13th largest producer of palm oil. In 2010, it was estimated that Cameroon produced 230,000 tons annually (MINADER, pers. com). Oil palm production in Cameroon increased following the drop in the prices of cocoa and coffee in the early 1990s, which at that time were the major commercial farming crops in the country. This caused many smallholders in the ecologically suitable areas to switch to planting oil palm (Ngando et al. 2011). This is further illustrated by the fact that the purchase of germinated oil palm seeds (chitted nuts) by smalland medium-sized farmers at the Centre for Oil Palm Research at La Dibamba (Cameroon) rose from 20\% of the total production in 1996 to an average of $60 \%$ during the past 10 years. It is thus estimated that about 5,000 ha of oil palm were planted by smalland medium-sized farmers each year during the last decade, making a total of about 90,000 ha for the non-industrial palm grove in Cameroon (Bakoume and Mahbob 2006). This increase in the number of oil palm smallholders and oil palm plantations has equally resulted in an increase in the number of artisanal oil palm presses in the palm oil production basins in Cameroon. The upsurge has been more in communities around the oil palm agro-industrial corporations of SOCAPALM, CDC and PAMOL $\mathrm{Plc}$, probably initiated by the operations of the corporations. 
The present survey has two main objectives:

- To investigate the artisanal processing of fresh fruit bunches (FFB) into red oil and the processing of the kernel into kernel oil.

\section{More specifically to}

- determine those involved in artisanal palm oil processing

- identify the different types of artisanal palm oil presses in the production basins

- describe each processing type (value chain) and the relative advantage of one type over the other (with respect to time, quantity of oil/ton FFB or extraction efficiency and quality control methods put in place)

- assess the return to labor, milling charge and contribution to income for each type of oil palm mill
- determine those involved in the processing of kernel into kernel oil and the production of local soap and by-products, and describe the methods and profit margins in this type of business.

- To investigate the commercialization of $\mathrm{CPO}$ in domestic markets.

\section{More specifically to}

- identify those involved in the sale of CPO in domestic markets

- describe the market chains - artisanal or informal (wholesalers and retailers alike) and industry

- describe the fluctuation in the prices of a liter of CPO in the local market over the years in village, town and city

- assess the contribution of income generated from sales of CPO to household livelihood. 


\section{Materials and methods}

This study was carried out in three major palm oil basins in Cameroon located around the oil palm agro-industrial zones of Eseka, Lobe and Dibombari, respectively in Centre, South-West and Littoral regions of the Republic of Cameroon.

These regions meet the required biophysical conditions for the growth and development of oil palm. These conditions as put forth by Better Crops International (1999) include:

- High temperatures all year round, between 25$28^{\circ} \mathrm{C}$.

- Sufficient sunshine: At least five hours of sun per day.

- High precipitation: Evenly distributed rainfall $1,800-2,400 \mathrm{~mm} /$ year without dry spells for more than 90 days; higher rainfall can be tolerated as long as soils are well drained.
- Soils: Oil palm prefers rich, free-draining soils, but can also adapt to poor soils with adequate use of fertilizer.

- Low altitude: Ideally below 500m asl.

Agriculture, including palm oil milling, is the predominant economic activity in these regions and serves as the main source of livelihood for over $90 \%$ of the population. This study was carried out for two months that is, one month of field work and data collection, and another for data analysis and reporting. Secondary data (literature review), interviews, field observations and survey methods were applied in order to obtain the required information.

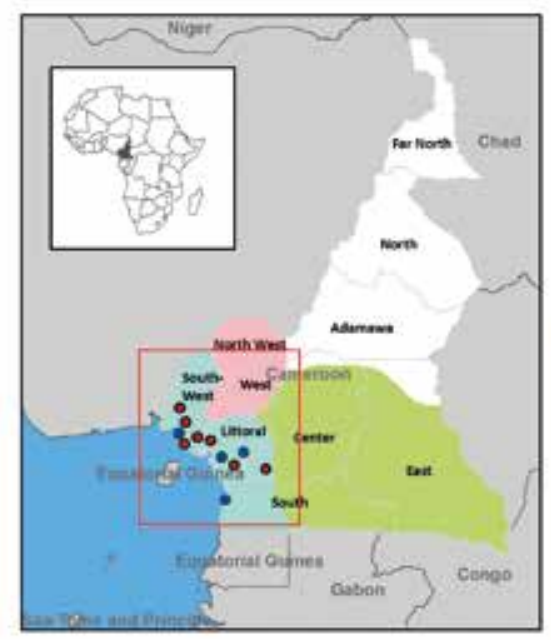

\section{LEGEND}

- Mes net hrolived in the FONUDER project

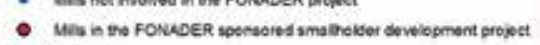

Fini] stodracess

Movt watabie ares for of palm culvoten

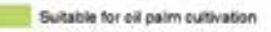

Leas sulable for of paim cumbasen

Not watio for oll paim custuation

80: socrenum ionere socuteon

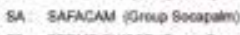

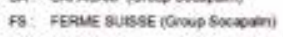

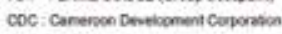

ru: puva

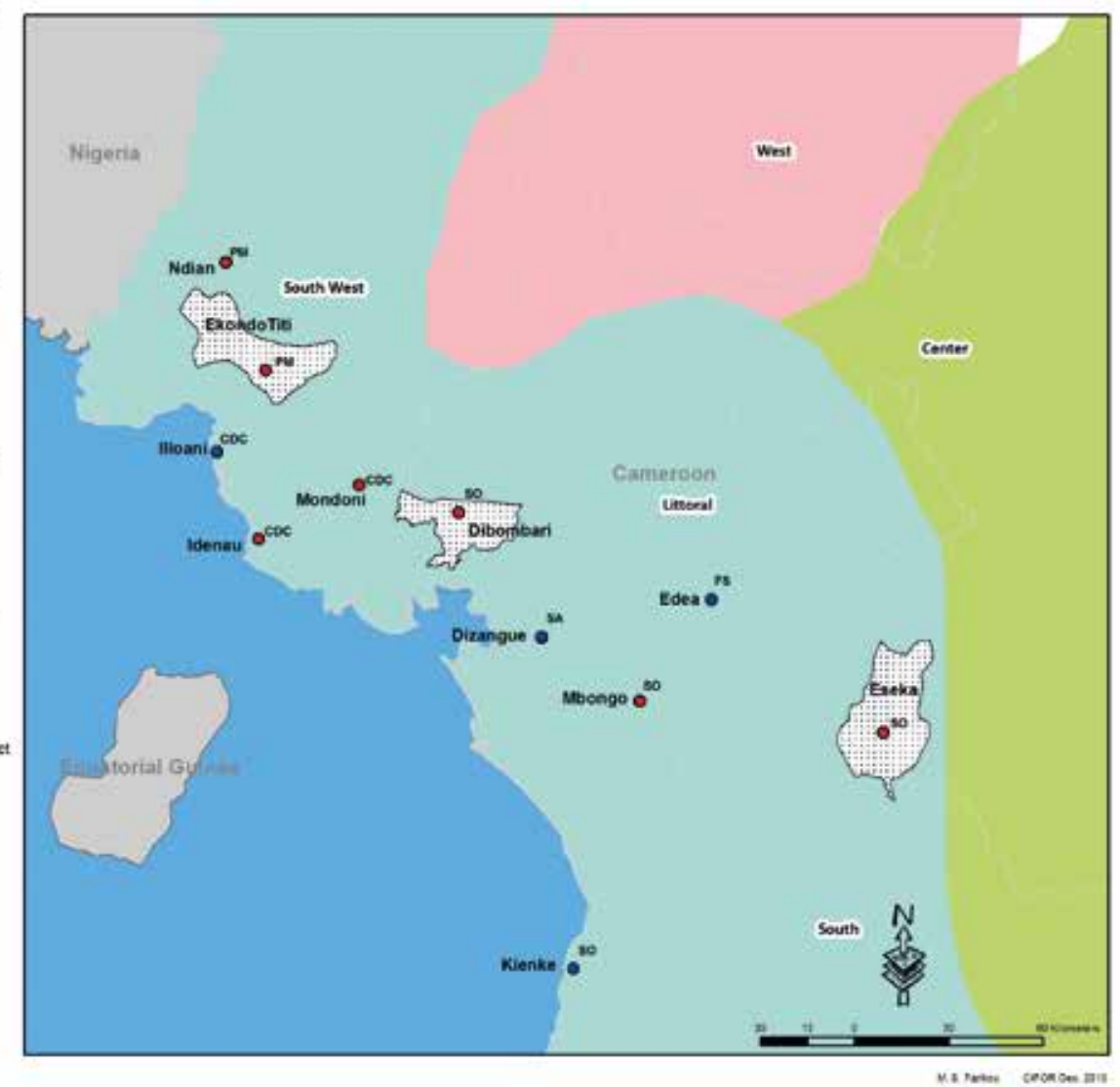

Figure 1. Map of Cameroon showing study locations 
During the field survey, the representative agroindustrial corporation of the area was visited and the objectives of the study discussed with a contact person in charge of smallholders in the environment. The villages to be surveyed were systematically selected based on the availability of palm oil mills, smallholders and intermediaries. Structured and semi-structured interviews were conducted to randomly selected respondents in the villages within the areas.

Questionnaires were administered to at least 50 respondents in each zone, ranging from owners and/or managers of artisanal oil palm mills to smallholders and intermediaries (men, women and youths) who take part in the transformation and commercialization of red palm oil (RPO) in the respective areas. Informal interviews were also conducted with women/men who buy and sell palm oil in local markets. Information was also obtained through observation, dialogue and listening. Photographs of the different types of presses, and milling activities with labor, were taken in the different zones.
Data collection sheets were prepared in accordance with the main and specific objectives of the study. Information obtained from the questionnaires was transmitted into a database for eventual analysis using Microsoft Excel 2010. Descriptive statistics was applied with use of tables, frequencies and bar charts.

The net returns (NR) were calculated as: $\mathrm{NR}=\mathrm{TR}-\mathrm{TC}$

Where, $\mathrm{TR}=\mathrm{P}_{\mathrm{i}} \mathrm{Q}_{\mathrm{i}}$, and TC $=\sum_{1=0}^{\mathrm{n}} P_{x i} X_{i}$

NR is the net return, TR, total revenue from sales per ton of palm oil produced, $P_{i}$, price per ton of oil, $Q_{i}$, quantity of sales made, TC, total cost of operation per ton of oil produced, $P_{x i}=$ the price of the $\mathrm{i}^{\text {th }}$ input, and $X_{i}^{i}$ is the $\mathrm{i}^{\text {th }}$ input. (Ross et al. 2001). 


\section{Results and discussion}

\subsection{Small-scale artisanal milling}

Before the advent of artisanal mills/presses, smallholders had local/wild varieties that they processed using traditional methods, either by pounding cooked fruits in large wooden or concrete mortars with wooden pestles or by foot-trampling the cooked but cold fruits in specially constructed wooden troughs. The oil was extracted by pressing the pounded nuts with the aid of a bag and a stick.

The agro-industrial corporations later introduced the improved variety wherein the smallholders had an agreement to supply their produce to them at a cost that varied with the area and corporation. As time went on, production increased and often the corporation could not meet up with the processing of all FFBs from smallholder farms. This occurred because accessibility to some farms also hindered transportation. Moreover, the administrative procedures put forth to accept FFBs and pay for the product delivered were considered inappropriate and too slow by the smallholders. The tonnage was reduced at the weighing bridge of the corporation either because the FFBs were too bruised, not yet mature or rotten. It became a cause for concern to the smallholders and they devised a means to curb the losses and generate more income from processing of FFBs to palm oil. It was based on this precept that they resorted to artisanal transformation of FFBs to crude palm oil.

Two distinct palm-oil production seasons were recorded: peak and low. The peak season ranged from February to May, and low season from June through January. Triangulation from the respondents revealed a transition period from low to peak season, which some smallholders described as mid-peak. Taking the mid-peak season into consideration, the peak season was recorded from February to May, low season from June to September and the transition or mid-peak season from October to January.

\subsection{Processing of fresh fruit bunches (FFBs) into red oil}

\author{
Those involved in artisanal palm oil \\ processing
}

The personal information and type of service provided by respondents indicated a trend of those involved in artisanal palm oil processing (POP) in the study area.

Gender: More men are involved in artisanal milling than women in all areas. In Eseka, up to $20 \%$ of women had an oil palm plantation (OPP) or a palm oil mill (POM). In Lobe and Dibombari, less than $20 \%$ of the women were involved in artisanal milling. Women were limited by land tenure and acquisition rights to own a plantation, as well as by capital and skills needed to own and manage activities in palm oil mills.

Age group: A greater percentage of the respondents were within the age range of $31-40$ and $41-50$ years. This illustrates that it is a business for the active population.

Education: The levels of education were basically primary school leavers and junior high school drop outs. Information from the respondents with high school and university certificates showed that over $90 \%$ of them use the business as a means to raise capital for further studies or to travel abroad. Good management of the OPP and POM requires education to aid in transfer of improved practices in palm oil production (Ibitoye et al. 2011).

Marital status: At least $70 \%$ of the respondents in the area were married and had their families actively participating in the processing of red palm oil. Unlike singles/bachelors, the married people had their families as immediate source of labor. In Eseka and Dibombari, family members were involved in all stages of the milling activities whereas in Lobe, hired labor was dominant. 
Table 1. Distribution of respondents in the study areas.

\begin{tabular}{|c|c|c|c|}
\hline \multirow{2}{*}{ Variables } & \multicolumn{3}{|c|}{ Percentage of respondents per area } \\
\hline & Eseka & Lobe & Dibombari \\
\hline \multicolumn{4}{|l|}{ Gender } \\
\hline Male & 78 & 86 & 86 \\
\hline Female & 22 & 14 & 14 \\
\hline \multicolumn{4}{|l|}{ Age group } \\
\hline$\leq 30$ & 22 & 20 & 18 \\
\hline $31-40$ & 28 & 28 & 32 \\
\hline $41-50$ & 24 & 30 & 32 \\
\hline $51-60$ & 8 & 10 & 8 \\
\hline$>60$ & 18 & 12 & 10 \\
\hline Average ages (years) & 43.4 & 43 & 41.2 \\
\hline \multicolumn{4}{|l|}{ Ethnic group } \\
\hline Native & 94 & 32 & 76 \\
\hline Non-native & 6 & 68 & 24 \\
\hline \multicolumn{4}{|l|}{ Level of education } \\
\hline None & 4 & 0 & 2 \\
\hline Primary & 36 & 40 & 3 \\
\hline Junior high school & 38 & 36 & 42 \\
\hline High school & 14 & 16 & 14 \\
\hline University & 8 & 8 & 12 \\
\hline \multicolumn{4}{|l|}{ Marital status } \\
\hline Single & 20 & 14 & 28 \\
\hline Married & 78 & 78 & 70 \\
\hline Widow(er) & 0 & 6 & 2 \\
\hline Divorcee & 2 & 2 & 0 \\
\hline
\end{tabular}

Source: Field survey, 2012

Ethnic group: The indigenes in the study area are: Bassa in Eseka, Balondo (Oroko) in Lobe and Ahbor (Douala) in Dibombari. In Eseka and Dibombari areas, milling of red palm oil is dominated by natives and in Lobe by non-natives. They get involved in ownership of oil palm plantations, palm oil mills, buying of FFBs from other smallholders, hiring of labor to process FFBs/loosed nuts and sales of CPO.

Also, in Eseka, women have the same access to land for establishment of oil palm plantation and/or palm oil mill as the men though these rights were limited to natives only. The customary rights in this area did not prohibit indigenous women from owning/ inheriting land, but did not grant access to land to non-indigenes. In Lobe and Dibombari zones, natives and non-natives alike had access to land for various uses provided they are financially viable and meet up with the conditions put forth by the traditional council.

\section{Type of service providers/processors}

Mill owner only: Those who own palm oil mills and either employ or do not employ a manager.

Mill manager only: Those who do not have a mill but have been hired/employed by the owner or common initiative group (CIG) to manage the POM.

Smallholder (SH) only: Owners of oil palm plantations (OPP). They neither own a POM nor buy FFBs. They process only fruits from their farms and pay mill charges.

Intermediary only: Men, women or youths who buy FFBs from SHs and process. Do not own a POM or OPP.

Mill owner and smallholder: Those who own mills and also have OPP. 
Mill owner, smallholder and intermediary: Those who own POMs, OPPs and also buy FFBs from other smallholders.

Mill manager and smallholder: Those hired by a POM owner to manage the mill. They also have an OPP.

Mill manager and intermediary: Those hired by a POM owner to manage the mill. They also buy FFBs from $\mathrm{SH}$ to process.

Mill manager, smallholder and intermediary: SHs with OPP, hired by a POM owner to manage his mill. They also buy FFBs from other SHs to process.

Smallholder and intermediary: A smallholder with OPP who buys FFBs from other $\mathrm{SH}$ in addition to his/her harvests to process, but neither owns nor manages a POM.

The distribution of the service providers are represented in Table 2.

Mill managers and smallholders were the dominant service providers in the study area with a frequency of 34 respondents. The degree of complexity in palm oil processing in Eseka is limited with manual press dominating the POMs and few motorized presses. As such, mill owners are virtually the smallholders in the area. In Lobe and Dibombari, managers are hired to assist in the POM and owners get involved in farming, intermediary businesses and other incomegenerating activities.

\section{Types of artisanal palm oil presses}

There are two distinct methods of extracting oil from the digested material. The "dry method" uses mechanical presses and the "wet" method uses hot water to leach out the oil. The objective of the "dry" method is to squeeze the oil out of a mixture of oil, moisture, fiber and nuts by applying mechanical pressure on the digested mash.

The different types of presses identified in the three areas reflect the degree of complexity of the POMs. Generally, six types of palm oil presses were observed and identified (from literature study) in the study area. They include

- manual press without a digester locally called tournée tournée (manual vertical press); this press adopts the wet process where-in the sterilized fruits are poured into the digester and the fruits macerated by manually turning the vertical shaft to extract a mixture of oil and water, which is collected at the base. The resultant mixture of water and oil is poured into larger drums. This

Table 2. Distribution of respondents by type of service provider/processor.

\begin{tabular}{lcccc}
\hline \multirow{2}{*}{ Type of service provider } & \multicolumn{2}{c}{ Frequency of service provider in: } & \multirow{2}{*}{$\begin{array}{c}\text { Total frequency in } \\
\text { the three areas }\end{array}$} \\
\cline { 2 - 4 } & Eseka & Lobe & Dibombari & 3 \\
Mill owner only & 0 & 1 & 2 & 2 \\
Mill manager only & 0 & 1 & 1 & 16 \\
Smallholder (SH) only & 7 & 7 & 2 & 12 \\
Intermediary only & 6 & 2 & 4 & 29 \\
Mill owner and smallholder & 15 & 7 & 7 & 7 \\
Mill owner and intermediary & 0 & 2 & 5 & 14 \\
Mill owner, smallholder and & 2 & 2 & 10 & 34 \\
intermediary & 14 & 13 & 7 & 7 \\
Mill manager and smallholder & 0 & 1 & 6 & 16 \\
Mill manager and intermediary & 2 & 10 & 4 & 10 \\
Mill manager, smallholder and & & & & 150 \\
intermediary & 4 & 4 & 2 & \\
Smallholder and intermediary & 50 & 50 & 50 & \\
Total & & & & \\
\hline
\end{tabular}

Source: Field survey 2012 
mixture is then boiled to extract the oil that is going to suspend.

- motorized press (motorized horizontal screw press); this press adopts the wet process technique where-in sterilized fruits are poured into the digester and the fruits are macerated. Hot water is continuously poured into the digester at a regular rate to wash off the released oil. The resultant mixture of water and oil is poured into larger drums. This mixture is then boiled to extract the oil that is going to suspend.

- manual or hand press with a digester adapted to a car engine [digester with separate metallic cage press (hand operated screw press)]; this press adopts the dry process. A vertical digester adapted to a car engine is used in the maceration process. A mixture of oil, moisture, fiber and nuts is collected at the base and this mixture is handpressed in a metallic cage to extract the oil.

- digester with separate hydraulic press; this press adopts the dry process technique wherein sterilized fruits are poured into the digester and the fruits are macerated. A mixture of oil, moisture, fiber and nuts is collected at the base and this mixture is pressed using a hydraulic press to extract the oil.

- combined motorized hydraulic digester and press system (digester screw press); this press also adopts the dry process technique. In this press, the digester is linked to the press through an operating table upon which cage presses can slide between stations.
- semi-automated press; this press also adopts the dry press technique. Here little or no human labor is needed as the majority of the different stages (from loading for sterilization through to pressing) involved in oil extraction are mechanized. This press system is the most efficient and the most expensive and that therefore makes it unaffordable to the majority of smallholders.

The manual vertical press was the most frequent type of processing equipment in the area, while semi-automated was the least frequent (2), found only in Ekondo-Titi and Maleke, respectively in Lobe and Dibombari areas. They were owned and managed by PALMAGRO and FACAM common initiative groups (CIGs) respectively. Generally, the following activities were carried out in the POMs as represented on the scheme below.

The processes above apply to presses with digesters such as digester with separate manual metallic cage press, combined motorized hydraulic digester and press system (digester screw press), digester with separate hydraulic press and semi-automated press. The manual vertical press and motorized horizontal screw press do not have digesters. As such, the boiled nuts are loaded directly into the press and nuts are pressed either manually or mechanically.

Table 3. Type of processing equipment used

\begin{tabular}{lcccc}
\hline & \multicolumn{3}{c}{$\begin{array}{c}\text { Frequency of equipment used by } \\
\text { respondents }\end{array}$} & $\begin{array}{c}\text { Distribution of types of } \\
\text { Type of processing equipment }\end{array}$ \\
\cline { 2 - 4 } & Eseka & Lobe & Dibombari & \\
\hline Manual vertical press & 44 & 1 & 22 & 67 \\
Motorized horizontal screw press & 6 & 0 & 25 & 31 \\
$\begin{array}{l}\text { Combined motorized hydraulic digester } \\
\text { and press system (digester screw press) }\end{array}$ & 0 & 5 & 0 & 5 \\
$\begin{array}{l}\text { Digester with separate manual metallic } \\
\text { cage press (hand- operated screw press) }\end{array}$ & 0 & 35 & 1 & 36 \\
$\begin{array}{l}\text { Digester with separate hydraulic press } \\
\text { Semi-automated press }\end{array}$ & 0 & 8 & 1 & 9 \\
\hline
\end{tabular}

Source: Field survey 2012 


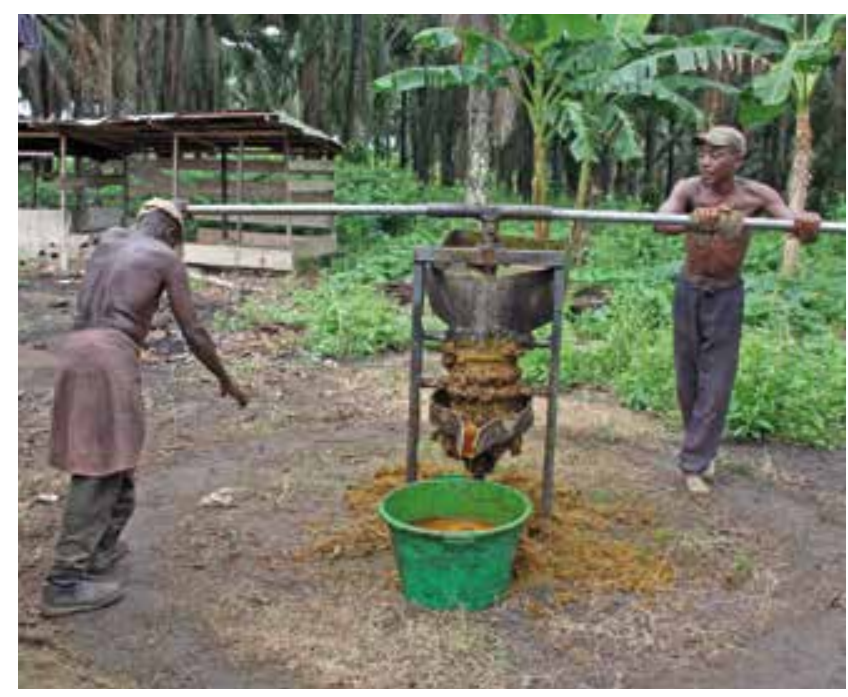

Picture 1. Manual vertical press

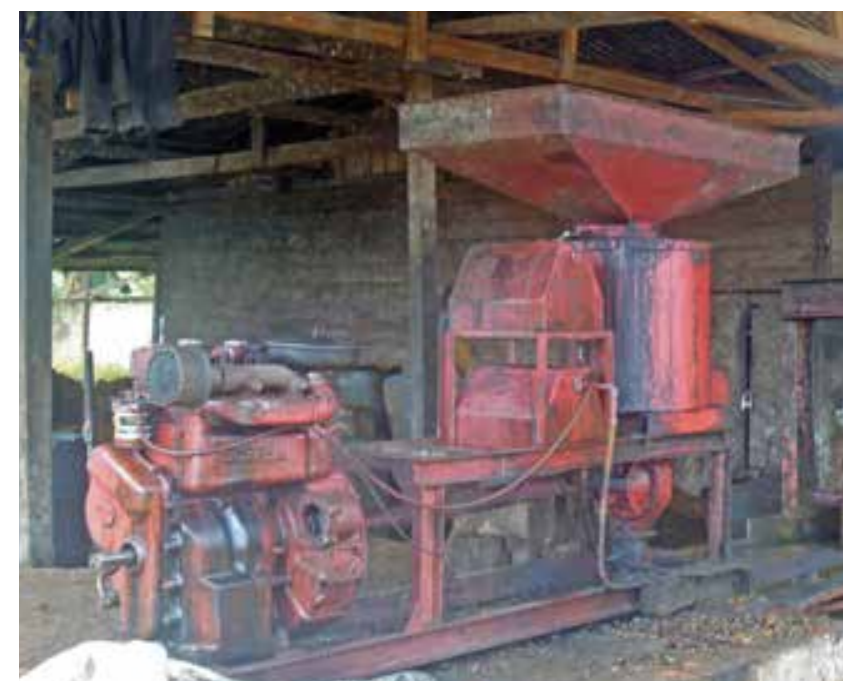

Picture 3. Combined motorized hydraulic machine and press system

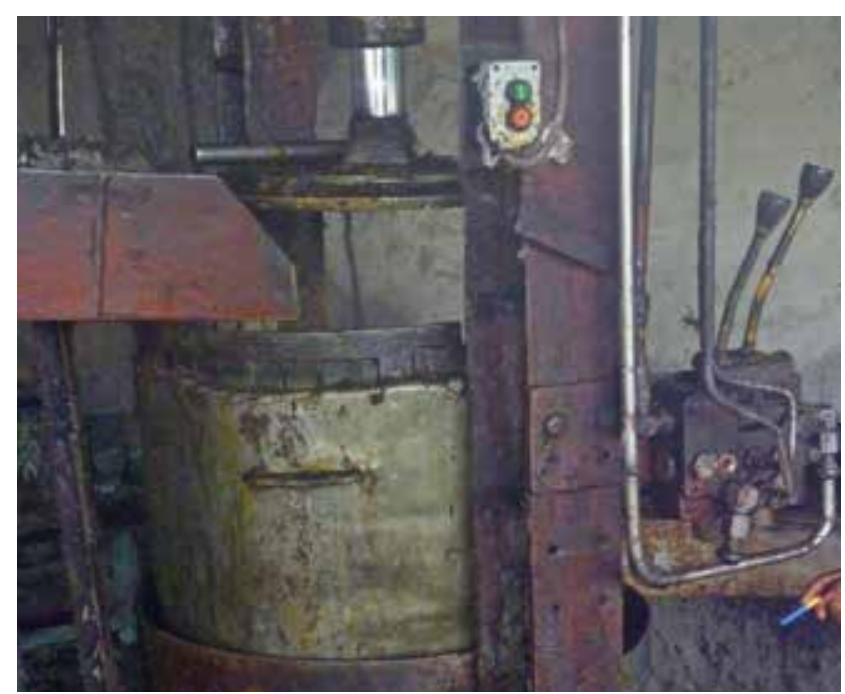

Picture 5. Semi-automated press (side view)

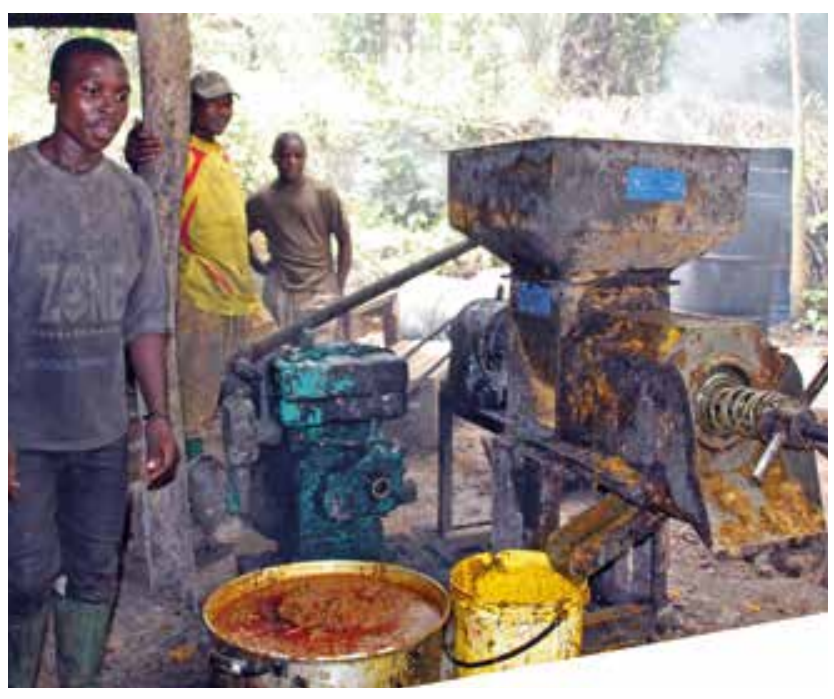

Picture 2. Motorized horizontal press

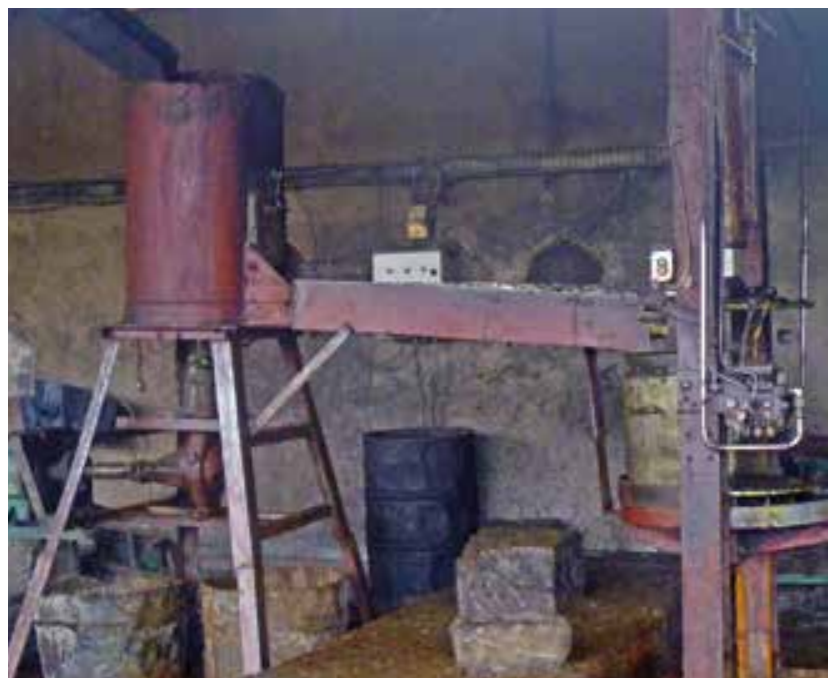

Picture 4. Semi-automated press (side view)

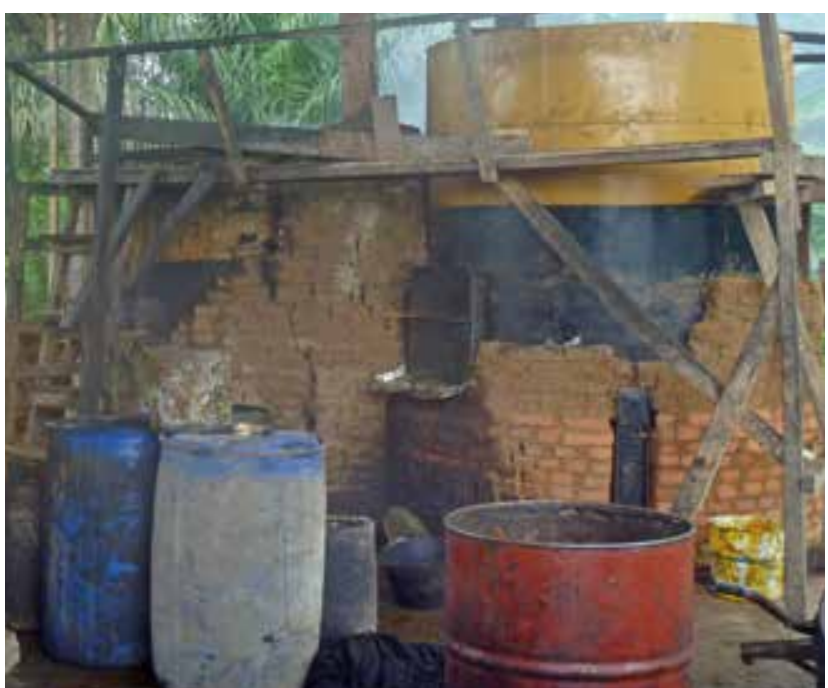

Picture 6. In-built metallic drums for CPO clarification 


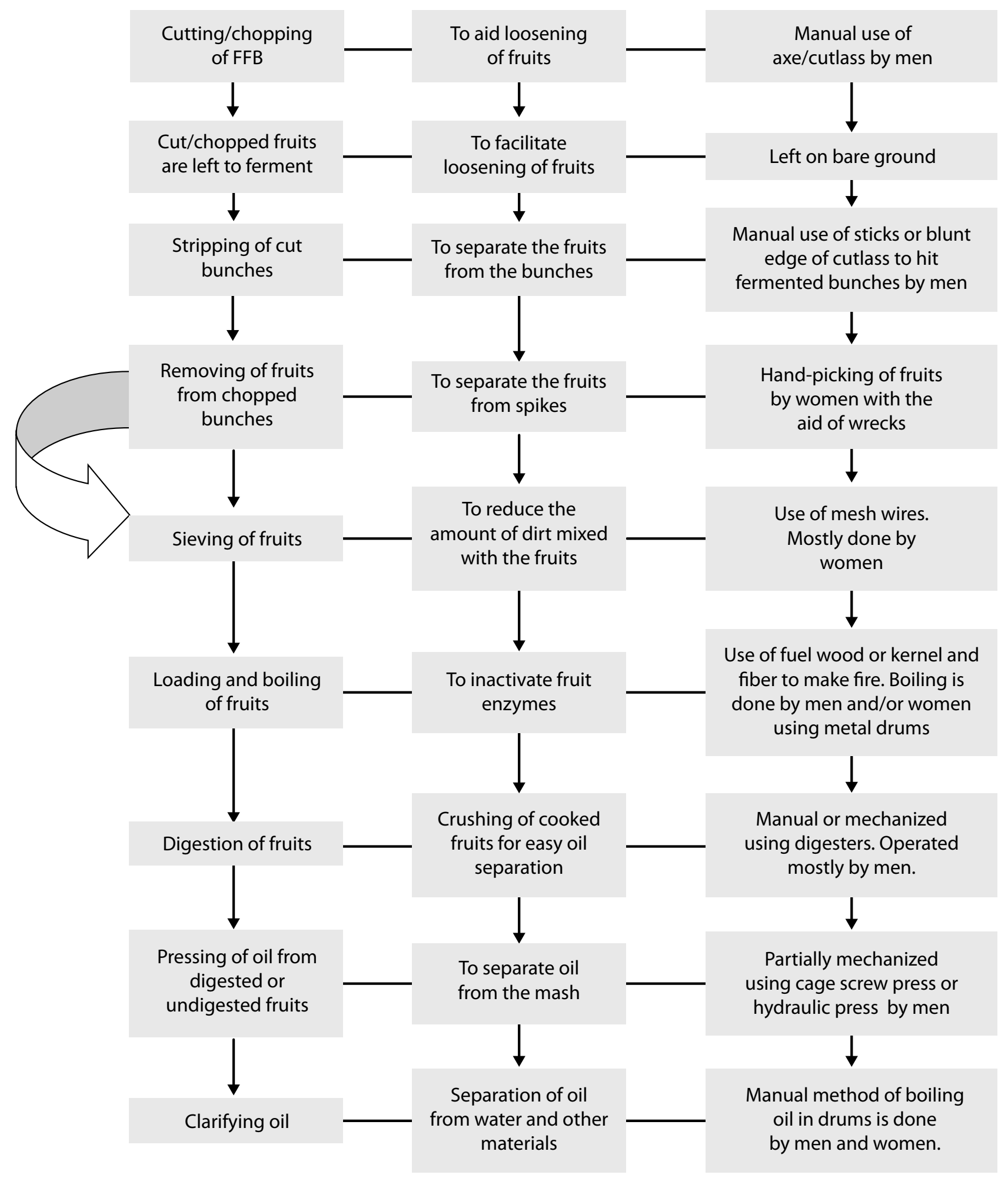

Figure 2. Schematic representation of milling activities 
In the Lobe area, a section of the communities (Ekondo-Titi and Bekora) have been allocated a specific area for construction of POMs and processing of palm oil. These sites were described as industrial zone for the production of "Red Gold". This shows the recognition of red palm oil processing as an industrial activity in the area. It provides job opportunities to inhabitants for both skilled (such as mill managing) and unskilled labor (such as harvesting, chopping and cutting of FFBs, stripping, loading, boiling, pressing of loosed nuts and clarification of red palm oil).

\section{Processing (value-chain) and relative advantage of various types}

\section{Processing}

The value chain of the mill was determined by the type of press used in processing the red palm oil. Six different types of presses were identified in the study area as represented above. The transformation of FFBs to CPO involves a number of activities. After harvesting, the FFBs are transported to the palm oil mill, allowed to ferment for an average of 5-7 days before FFBs are shredded into pieces. The major operating activities at the mills include splitting (cutting) and/ or chopping (shredding) of FFBs, stripping to separate fruits from bunches, selecting and sieving of stripped nuts using wreck and mesh wires respectively, loading and boiling of nuts, crushing of boiled nuts pressing and clarifying the red palm oil. Of these, only digestion and pressing are either fully or partially mechanized.

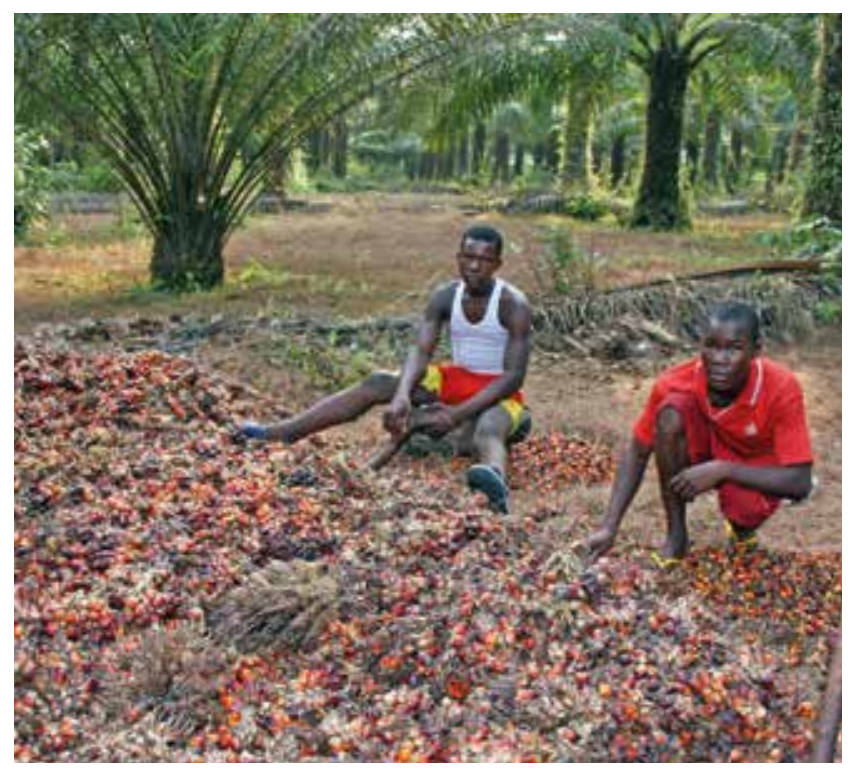

Picture 7. Chopped or shredded FFBs
Splitting/Chopping of FFBs: This process involves the use of an axe or cutlass and it is usually performed by men due to the strength required. Splitting is usually done on bare ground. Splitting or chopping results in fruit bruises that lead to reaction within the oil cells thereby increasing the free fatty acid (FFA) content of the oil. In order to limit this reaction within the oil cells, FFB should be handled with care (Ngando et al. 2011).

Storage of cut/chopped bunches: After chopping/ cutting of the FFBs, they are stored in heaps for 5-7 days to facilitate easy loosening or removal of fruits from spikelet. This method of storage facilitates the wilting of the tissue connecting the fruit to the bunch/spikelet, thereby causing the fruit to easily detach from the bunch/spikelet during stripping. The fermentation process further increases the FFA content. Poor and lengthy storage of fruits lead to a considerable increase in FFA that affects the quality of palm oil produced from the loose nuts (Corley et al. 2003; Owolarafe et al. 2008; Ngando et al. 2011). Where quality control methods are applied in processing, it is recommended that palm fruits should be processed within 48 hours after harvesting. This is to stop the action of lypolytic enzymes and prevent the production of FFA (Poku 2002). The field survey revealed that these fruits were stored for some days prior to processing due to the following reasons:

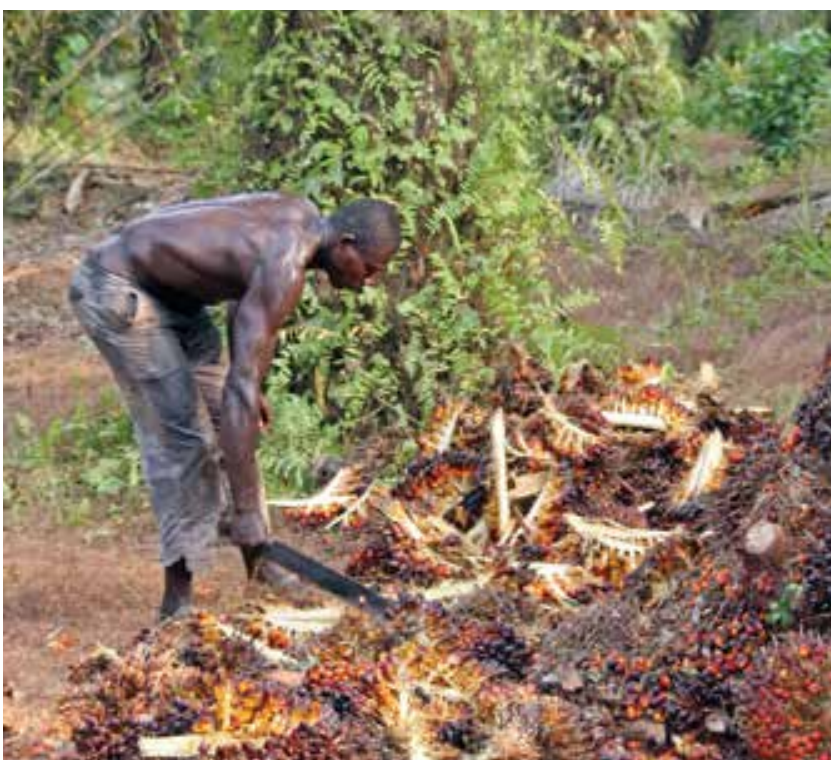

Picture 8. Halves of cut FFBs 
i) Difficulty in the detaching of fruits from the bunch immediately after harvesting to prepare for boiling.

ii) Fruit storage is believed to increase oil content as the mesocarp of the fruits becomes soft and easier to press after storage and fermentation. This perception is in contrast to the findings of Badmus (1991) and Tan et al. (2009) who consider that the fermentation process results in low quality oil and increases FFA levels.

iii) Fruit storage is also believed to reduce the moisture content of the fruits, consequently leading to a lower quantity of palm-oil mill effluent.

Stripping of cut bunches: After softening of the fruits, these bunches are stripped using sticks or the blunt edge of a cutlass to remove any nut that is still attached to the bunch. Stripping is mostly done by men and the average cost per ton of FFB is 2,579 FCFA, 896 FCFA and 1,550 FCFA for Eseka, Lobe and Dibombari respectively.

Sieving: Sieving is done to reduce the amount of dirt mixed with the fruits before boiling. It is done with the use of locally fabricated mesh wires and usually by women. The average cost of sieving oil palm fruits stripped from a ton of FFB ranges from 1,971 FCFA

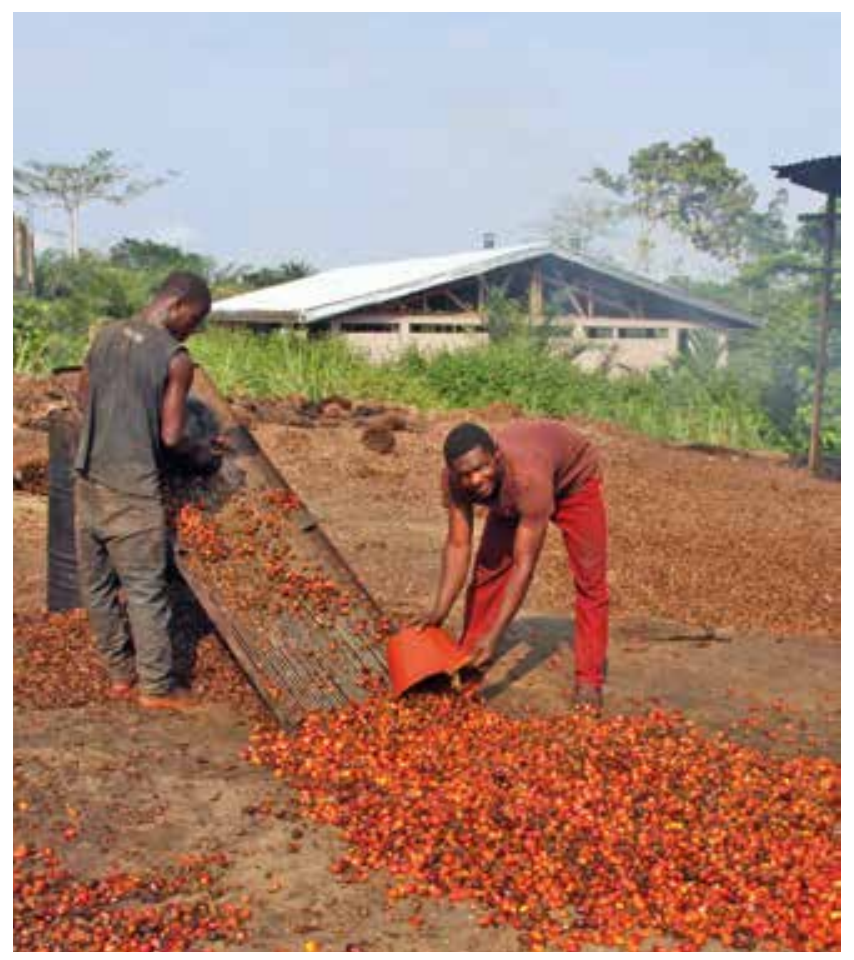

for Eseka, 681 FCFA for Lobe and 1,056 FCFA for Dibombari. After sieving, the nuts are loaded into metallic drums ranging from 200 liters as was observed in Eseka and some mills in Dibombari to 1,000 liters in volume as observed in Lobe and some mills in Dibombari as well. These drums were filled with at least $35-140$ liters of water depending on the size of the drum before boiling.

Boiling of fruits: After loading of the drums (on fire stand) with fruits and required quantity of water poured into it, fire is lit beneath using wood and palm kernel mixed with fibers from the waste of palm oil extraction. Fuel is constantly added to provide sufficient fire throughout the cooking. Old cloths and at times jute bags are placed over the filled drums to conserve heat and reduce the loss of vapor from the top. The fruits are expected to be ready after boiling on intensive heat for an average of four hours. Some processors allow the boiled fruits overnight on the fire to ensure they are well cooked. In such instances, the fruits are re-boiled (warmed) early in the morning, before starting with the digestion or pressing process. Boiling is considered to be one of the major operations in the processing of palm fruits. The objective of boiling is primarily to soften the fruits and also to inactivate enzymes, conditioning of nuts and coagulation of proteins (Babatunde et al. 2003; Chaw and Ma 2007).

\section{Digestion (Crushing) and pressing: Digestion is} the process by which boiled or sterilized fruits are macerated for easy separation of oil from the fiber. This involves crushing and detachment of the heat-weakened mesocarp from fruit nuts. This process is highly mechanized and most of the mills visited in the study area performed this operation with the aid of a machine. Pressing has two major processes: continuous and discontinuous (Jannot 2000). In the continuous process, the boiled fruits are pressed using either a manual vertical or motorized horizontal press. In this case, the oil mixed with water and sludge is collected at one end while the waste is emptied at another end. In the discontinuous process, the boiled fruits are crushed or digested in a separate machine and pressed to extract oil in another machine, which can either be joint or not to the previous one. After the fruits are crushed, the crushed material is pressed to release oil as shown in pictures 10 and 11 .

Picture 9. Sieving of palm fruits 


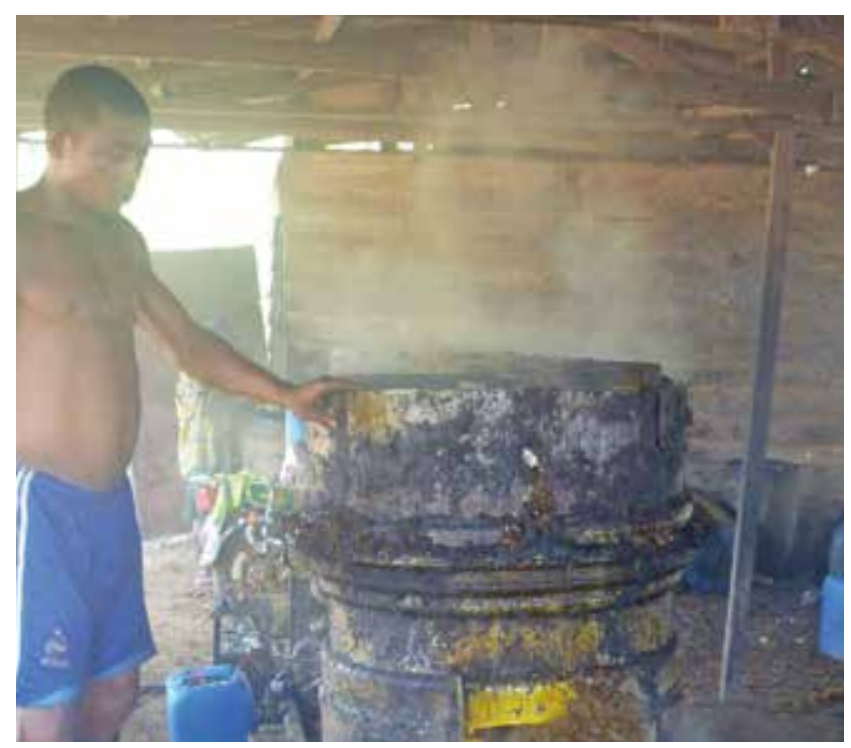

Picture 10. Crushed material emptied into metallic cage

With the combined motorized hydraulic digester and press system (digester screw press), the crushing/ digestion and pressing is done by a single machine; for the digester with separate manual metallic cage press (hand-operated screw press) or hydraulic press, the crushing of boiled fruits is performed by the mechanical digester and the pressing is done either by a separate hydraulic or metallic cage (hand-operated screw press).

The processing capacity of the metallic cage press (hand-operated screw press) is limited by the extra energy put in by the mill workers to load crushed fruits and to operate the equipment, whereas the hydraulic press does not require extra energy in the operation.

The combined motorized hydraulic digester and press system (digester screw press) is more economical in terms of labor, material and surface area required. It also generates more revenue than the manual vertical press and a motorized horizontal screw press. The introduction of the combined motorized hydraulic digester and press therefore improves on the milling efficiency and the capacity of processing equipment.

Clarifying: Clarification is the last major operation in the production of red palm oil. After oil processing, the sludge is steamed/boiled to separate the oil from the effluent. The clarifying process was either manual or mechanized in the mills visited. In POMs operating the manual vertical press and motorized

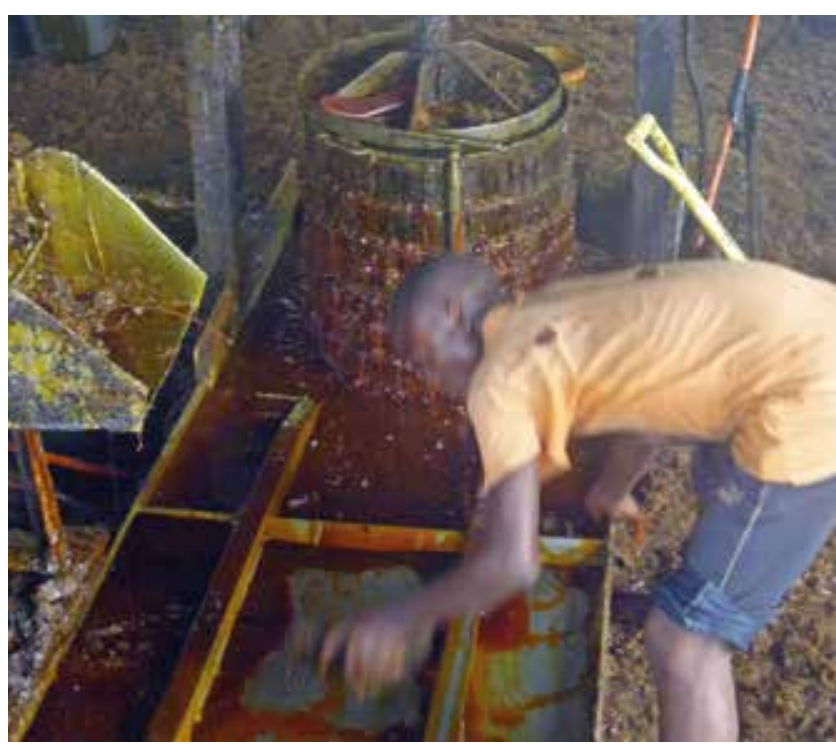

Picture 11. Crushed material pressed to extract RPO using hydraulic press

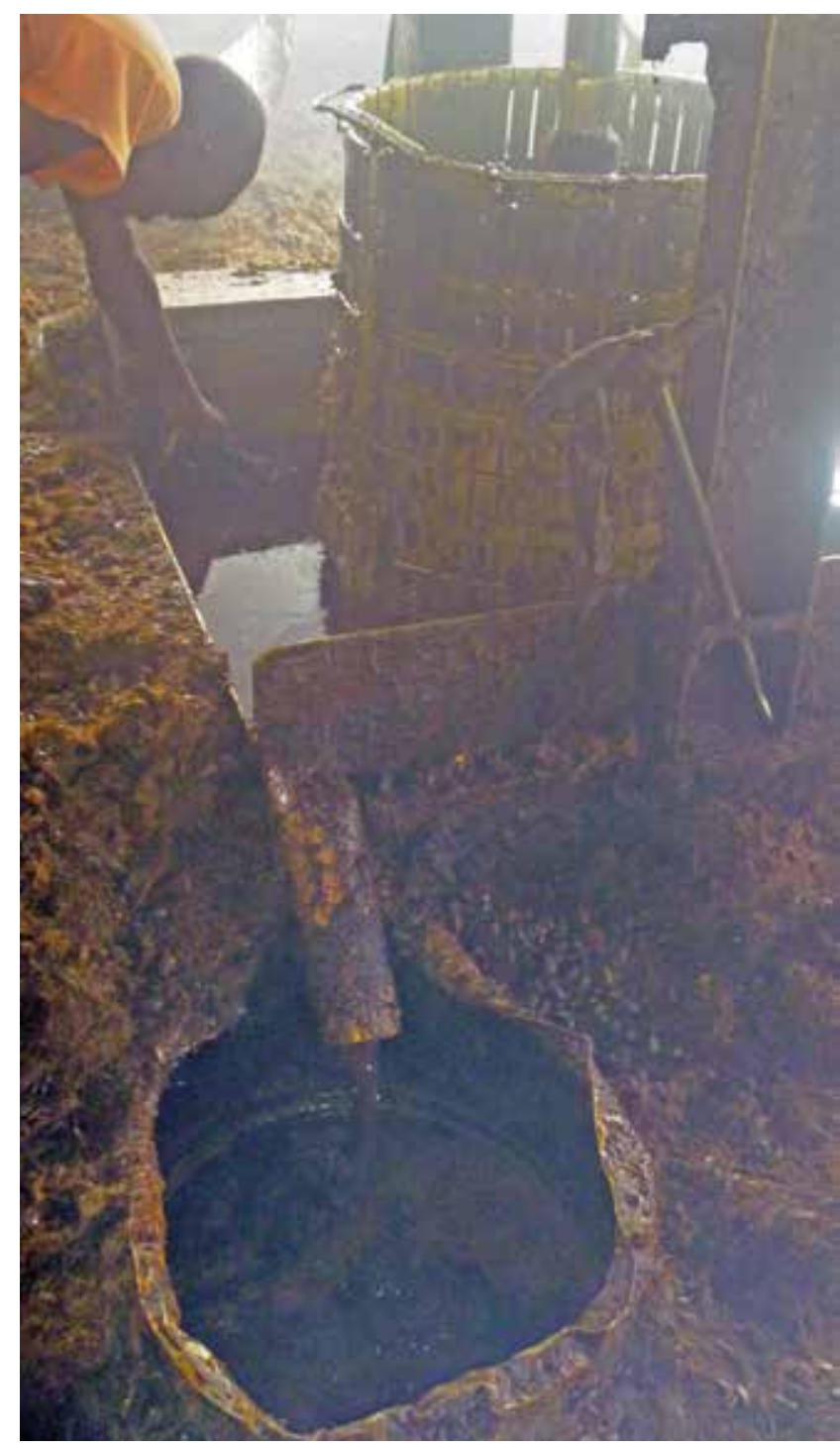

Picture 12. RPO directed into well built-in hole 


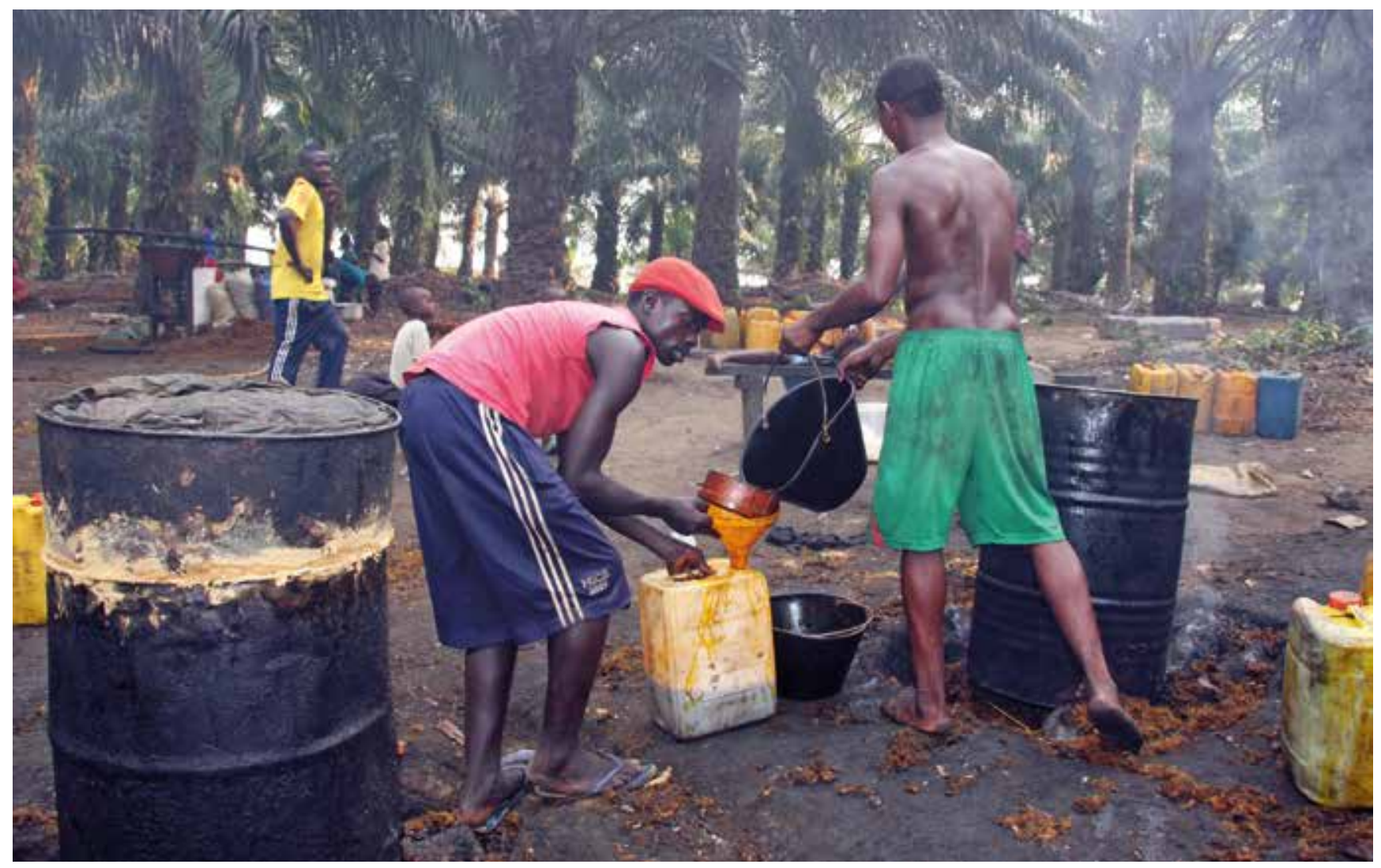

Picture 13. RPO filled into containers

This oil is collected and poured into drums of about 200-litre capacity and allowed to settle.

\section{Quality control methods put in place}

Some artisanal palm oil mills endeavor to put in quality control measures:

- During selection/sieving, bad nuts are separated from good nuts to ensure resulting $\mathrm{CPO}$ is of high quality.

- CPO collected as well as sludge is steamed and allowed to cool before filling in containers.

- The FACAM CIG that operates a semiautomated palm oil mill at Maleke sterilizes the FFBs before processing proper as a quality control method.

Other than the quality control methods which are already being put in place, more needs to be done, including:

- Reduction in the duration of the fermentation process so as to reduce the amount of FFA content in palm oil.

- Use of hygienic equipment by mill workers from one stage to the next during the milling process.

- Reduction in the moisture content of oil by carrying out efficient clarification. The duration of steaming should be monitored. The aim of steaming is to convert the crude oil to edible oil by removing impurities to desired levels in the most efficient manner. If done properly, the red-color, carotene-rich oil is produced with the retention of the beneficial carotene, tocopherols and tocotrienols, which are known to possess special nutritional attributes (Affandi 2010). If steaming is done for a longer duration, the $\mathrm{CPO}$ loses the red color and other desirable components.

- Storage of palm oil for a limited time to avoid it becoming rancid.

- Construction of well-dug trenches for the discharge of effluent from the mill.

- Recycling of empty fruit bunches (EFB) on farms as manure.

- Building pots in oven-like structures to minimize the release of heat into the surroundings, which is usually dangerous and uncomfortable to workers.

- Construction of chimneys in each mill such that smoke can easily go out in one direction.

- Introduction of modern machines with improved oil extraction rate. 
Production efficiency of the different types of presses

The different types of presses and their efficiency in the respective areas was assessed, as well as the average time taken for each type to process 1 ton of FFB and also the average quantity of CPO generated per ton of FFB in peak and low seasons. Results are presented by type of press (Cf. table 4). The extraction efficiency of POMs was obtained by extrapolation from the quantity (in liters) of CPO produced from 1 ton of FFB and the density of 1 liter of palm oil $0.9 \mathrm{~kg}$ (Ngom pers. comm.).

Therefore; Extraction efficiency $(\%)=\left(\mathbf{M}^{*} \mathbf{N}\right)$.

Where $\mathbf{M}=$ Quantity of oil in liters per ton of FFB and $\mathbf{N}=$ density $(\mathrm{kg})$ in volume per ton of FFB.

For example, if 1 ton $\mathrm{FFB}=200 \mathrm{~L}$ of $\mathrm{CPO}$, it implies $200 \times 0.9=180 \mathrm{~kg}=18 \%$

Table 4. Average production efficiency of different types of presses

\begin{tabular}{|c|c|c|c|c|c|c|}
\hline \multirow[b]{2}{*}{$\begin{array}{l}\text { Efficiency } \\
\text { parameter }\end{array}$} & \multicolumn{6}{|c|}{ Type of presses } \\
\hline & $\begin{array}{l}\text { Manual } \\
\text { vertical } \\
\text { press }\end{array}$ & $\begin{array}{l}\text { Digester with } \\
\text { separate } \\
\text { manual } \\
\text { metallic cage } \\
\text { press }\end{array}$ & $\begin{array}{l}\text { Motorized } \\
\text { horizontal } \\
\text { screw press }\end{array}$ & $\begin{array}{l}\text { Digester with } \\
\text { separate } \\
\text { hydraulic press }\end{array}$ & $\begin{array}{l}\text { Combined } \\
\text { motorized } \\
\text { hydraulic } \\
\text { digester and } \\
\text { press system }\end{array}$ & $\begin{array}{l}\text { Semi- } \\
\text { automated } \\
\text { press }\end{array}$ \\
\hline $\begin{array}{l}\text { Average time } \\
\text { (hours) to } \\
\text { process } 1 \text { ton }\end{array}$ & 8 & 6 & 5 & 4 & 3.5 & 2 \\
\hline $\begin{array}{l}\text { Average } \\
\text { quantity (in L) of } \\
\mathrm{CPO} / \text { ton of FFB } \\
\text { in peak season }\end{array}$ & 148.86 & 156.94 & 163.55 & 166.22 & 167.77 & 200.00 \\
\hline $\begin{array}{l}\text { Average } \\
\text { quantity (in } \mathrm{kg} \text { ) } \\
\text { per ton of FFB in } \\
\text { peak season }\end{array}$ & 133.98 & 141.25 & 147.20 & 149.60 & 151.00 & 180.00 \\
\hline $\begin{array}{l}\text { Extraction } \\
\text { efficiency (\%) in } \\
\text { peak season }\end{array}$ & $13.3 \%$ & $14.1 \%$ & $14.7 \%$ & $14.9 \%$ & $15.1 \%$ & $18.0 \%$ \\
\hline $\begin{array}{l}\text { Average } \\
\text { quantity (in L) of } \\
\text { CPO/ton of FFB } \\
\text { in low season }\end{array}$ & 142.77 & 149.44 & 152.04 & 160.83 & 162.22 & 200.00 \\
\hline $\begin{array}{l}\text { Average } \\
\text { quantity (in kg) } \\
\text { per ton of FFB } \\
\text { low season }\end{array}$ & 128.50 & 134.50 & 136.84 & 144.75 & 146.00 & 180.00 \\
\hline $\begin{array}{l}\text { Extraction } \\
\text { efficiency (\%) } \\
\text { in low season }\end{array}$ & $12.8 \%$ & $13.4 \%$ & $13.6 \%$ & $14.4 \%$ & $14.6 \%$ & $18.0 \%$ \\
\hline
\end{tabular}


Table 5. Relative extraction efficiency (\%) per ton of FFB during the peak and low seasons in the area

\begin{tabular}{lccccccccc}
\hline $\begin{array}{l}\text { Quantity of } \\
\text { CPO (in kg) } \\
\text { per ton of }\end{array}$ & $\begin{array}{c}\text { Extraction } \\
\text { efficiency } \\
\text { (\%) }\end{array}$ & \multicolumn{2}{c}{$\begin{array}{c}\text { Eseka (\% of } \\
\text { respondents) }\end{array}$} & \multicolumn{2}{c}{$\begin{array}{c}\text { Lobe (\% of } \\
\text { respondents) }\end{array}$} & $\begin{array}{c}\text { Dibombari (\% of } \\
\text { respondents) }\end{array}$ & \multicolumn{2}{c}{$\begin{array}{c}\text { Average in study } \\
\text { area (\%) }\end{array}$} \\
\cline { 3 - 11 } & & $\begin{array}{c}\text { Peak } \\
\text { FF) }\end{array}$ & $\begin{array}{c}\text { Low } \\
\text { (L) }\end{array}$ & P & L & P & L & P & L \\
\hline$\leq 150$ & $\leq 15$ & 74 & 78 & 42 & 66 & 50 & 66 & $\mathbf{5 5}$ & $\mathbf{7 0}$ \\
$151-200$ & $15.1-20$ & 26 & 22 & 58 & 34 & 50 & 34 & $\mathbf{4 5}$ & $\mathbf{3 0}$ \\
$201-250$ & $20.1-25$ & 0 & 0 & 0 & 0 & 0 & 0 & $\mathbf{0}$ & $\mathbf{0}$ \\
\hline
\end{tabular}

Extraction rates differ with the different equipment types.

From the table above, during the peak season, an average of $55 \%$ of respondents POMs had an extraction efficiency $\leq 15 \%$ in the three study areas. This was followed by $45 \%$, for extraction efficiencies ranging from $15.1-20 \%$. No POMs had extraction efficiencies of $20-25 \%$.

\section{The return to labor, milling charge and contribution to income}

The type of labor incorporated into the milling process was either family, hired or both. Hired labor was paid per activity, while family labor was compensated through different forms of motivations.
In Eseka, where family labor was dominant, some parents gave their children a portion of the oil palm plantation to control and process the FFBs to enable them to take care of their basic necessities. Others believed the milling activity was for the upkeep of the family; therefore, labor rendered by family members is not paid but motivated. This goes to confirm the findings of Adegeye (1993) that family labor is very important and minimizes cost in palm oil production.

Men and women were involved in different stages of production, with women actively involved in sieving, loading and boiling. The women contributed to family and/or hired labor in the process.

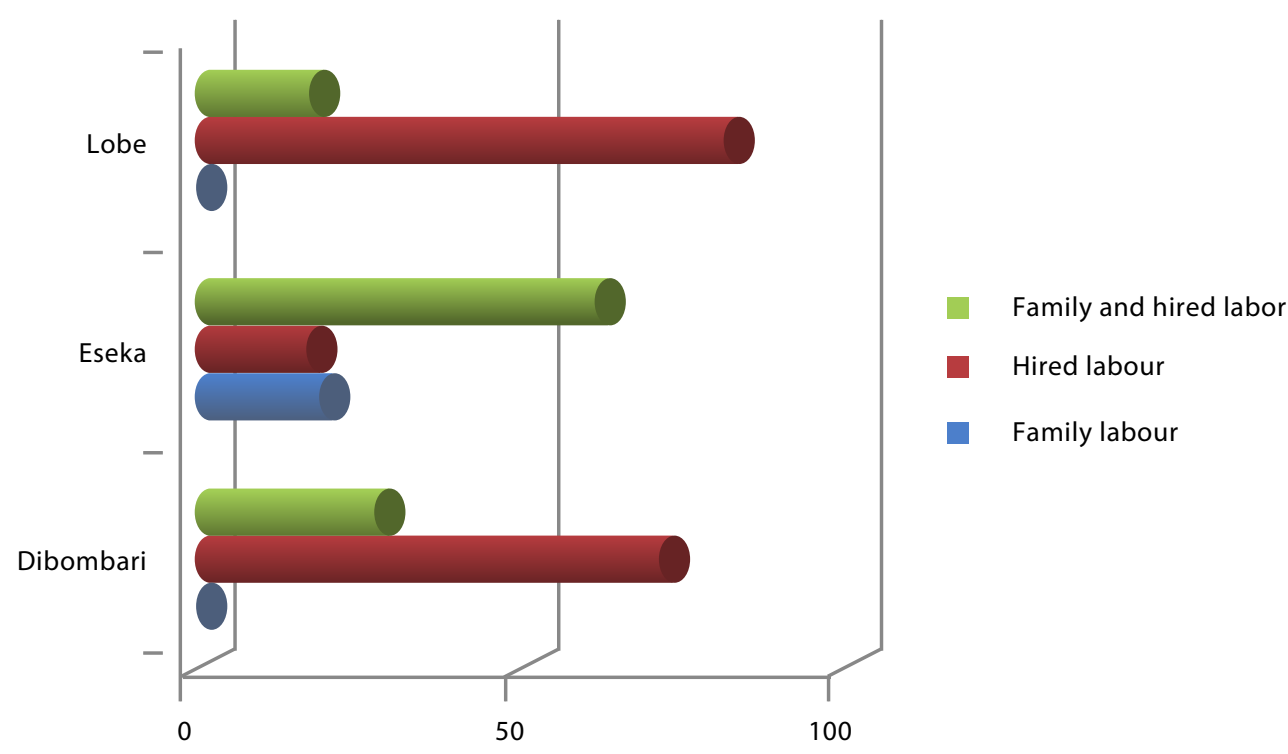

Figure 3. Contribution of family and hired labor 
Hired labor was paid for per activity and the average cost per activity in the areas was verified as represented on the table below. Artisanal oil palm processing clearly provides important indirect employment.

The high net income in Lobe area during peak season is probably due to the low cost of labor per activity relative to other areas and the total labor cost is less than that of Eseka and Dibombari. Furthermore, buyers come in during the dry season. During the rainy season, few buyers come in, leading to a drop in prices irrespective of the low cost of labor. Dibombari zone has a high net-income especially in low season because of accessibility. Buyers who find it difficult to go to Lobe or Eseka during the rainy season can always afford to go to Dibombari and thus the high prices for palm oil.

The contribution to income for each type of processing unit also varied in the study areas.

Table 6. Average labor cost per activity in the processing of 1 ton of FFB

\begin{tabular}{|c|c|c|c|c|c|}
\hline \multirow{2}{*}{\multicolumn{2}{|c|}{ Activity }} & \multicolumn{3}{|c|}{ Average cost (FCFA) per activity per area per 1 ton of FFB } & \multirow{2}{*}{$\begin{array}{l}\text { Average cost (FCFA) per } \\
\text { activity per } 1 \text { ton of FFB }\end{array}$} \\
\hline & & Eseka & Lobe & Dibombari & \\
\hline \multicolumn{2}{|c|}{ Chopping/shredding } & & & 1750 & 1750 \\
\hline \multicolumn{2}{|l|}{ Splitting } & 2125 & 1343 & 2023 & 1830 \\
\hline \multicolumn{2}{|l|}{ Stripping } & 2579 & 896 & 1550 & 1675 \\
\hline \multicolumn{2}{|l|}{ Sieving } & 1971 & 681 & 1056 & 1236 \\
\hline \multicolumn{2}{|l|}{ Loading } & 1156 & 528 & 936 & 873 \\
\hline \multicolumn{2}{|l|}{ Boiling } & 1300 & 979 & 1848 & 1376 \\
\hline \multicolumn{2}{|c|}{ Off-loading boiled nuts } & 1107 & 400 & 1081 & 863 \\
\hline \multicolumn{2}{|c|}{ Digesting (where necessary) } & & 600 & & 600 \\
\hline \multicolumn{2}{|l|}{ Pressing } & 3759 & 1878 & 2542 & 2726 \\
\hline \multicolumn{2}{|l|}{ Thinning/steaming } & 667 & 867 & 1024 & 853 \\
\hline \multirow[t]{2}{*}{ Total labor cost: } & Peak & 8845 & 7869 & 9723 & 8812 \\
\hline & Low & 8435 & 7869 & 9723 & 8812 \\
\hline \multirow[t]{2}{*}{ Milling cost: } & Peak & 7139 & 3727 & 5376 & 5414 \\
\hline & Low & 9410 & 3727 & 5376 & 6171 \\
\hline \multicolumn{3}{|l|}{ Other cost } & 758 & 1488 & 1123 \\
\hline \multirow[t]{2}{*}{ Total expenditure: } & Peak & 30437 & 30775 & 51642 & 37618 \\
\hline & Low & 30973 & 36238 & 52742 & 39984 \\
\hline \multirow[t]{2}{*}{ Gross income: } & Peak & 57160 & 66225 & 86090 & 69825 \\
\hline & Low & 76131 & 77675 & 106018 & 86608 \\
\hline \multirow[t]{2}{*}{ Net income : } & Peak & 26723 & 35451 & 34448 & 32207 \\
\hline & Low & 45158 & 41234 & 53276 & 46556 \\
\hline
\end{tabular}

Source: Field survey, 2012 


\subsection{The production of kernel oil and soap}

Some respondents in the production areas were involved in the extraction of kernel oil from palm kernel and also the production of soap from the last grade of palm oil. Fiber-kernel separators in use were observed only in the Dibombari area as in picture 14. Fiber-kernel separators are used to detach the palm kernel from the fibers and the kernels sold to buyers especially from Douala at an average price of 50 FCFA $/ \mathrm{kg}$. Loaded bags of kernels were observed as in picture 15 .

Respondents who owned fiber-kernel separators like that in picture 14 said a ton of FFB gives $100 \mathrm{~kg}$ of palm kernel (as in picture 15). The extraction rate for kernel oil is $3-4 \%$.

Average price $(\mathrm{FCFA})$ of kernel $=38 \mathrm{FCFA} / \mathrm{kg}$.

Average price $(\mathrm{FCFA})$ of kernel oil $=688 \mathrm{FCFA} /$ liter.

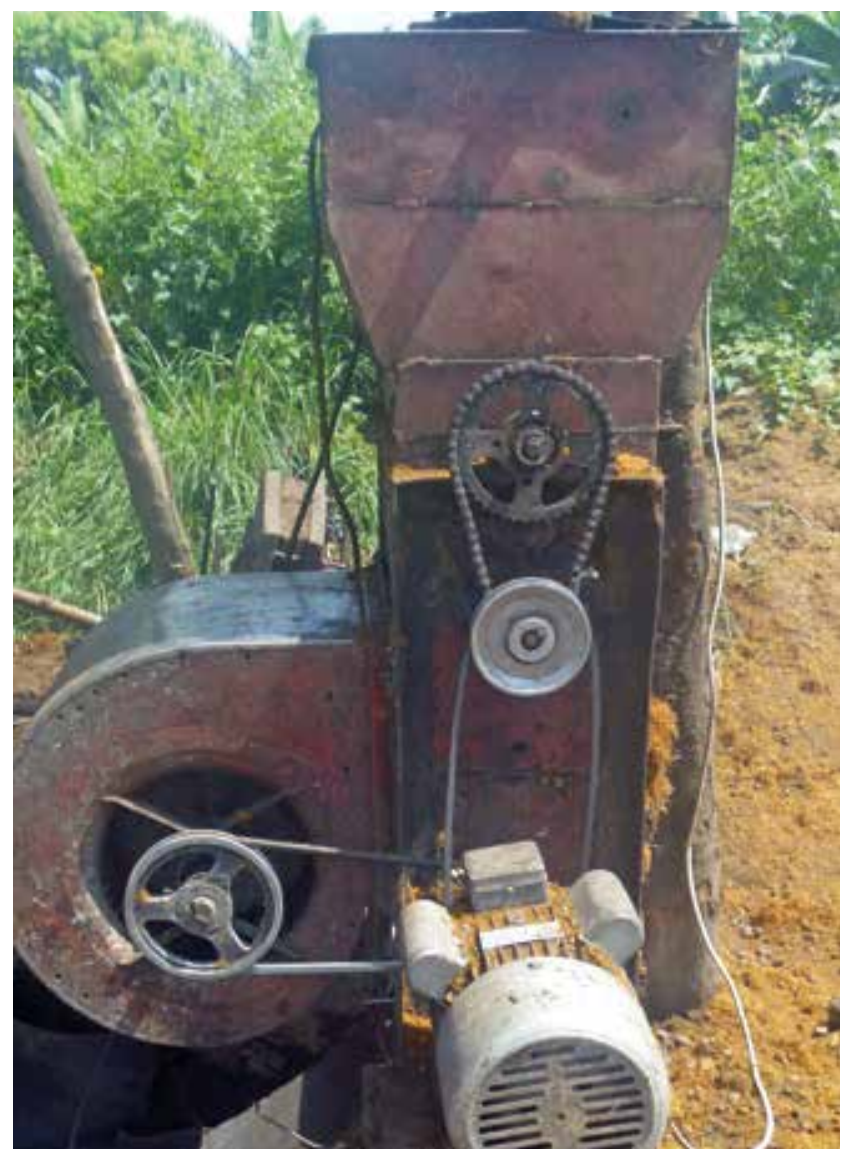

Picture 14. Fiber-kernel separator
Extraction of kernel oil from palm kernel was recorded in Eseka and Dibombari sections of the study. The production was in small scales for home use or sold at an average of 700 FCFA/L. Soap making was recorded only in Eseka and production was also in small scale for home use only. The soap was known locally as "sabula". Women were the only gender involved in soap making and extraction of kernel oil.

\section{Method of production}

Kernel oil: The extraction of kernel oil starts with the shelling of the palm nuts (Carrere 2010; FAO 2011). The endocarp is cracked with use-stones separating the shell from the kernel. The required quantity of kernel is sundried and later fried in a dry pot on heat to extract kernel oil. The sundried kernels are put in a pot and placed on the fire. The content of the pot is stirred over and over for about three hours. While stirring, the kernel produces oil until it burns up and can no longer produce oil. The pot is then removed from the fire and oil filtered, allowed to cool and later filled in containers to be sold in liters or used at home.

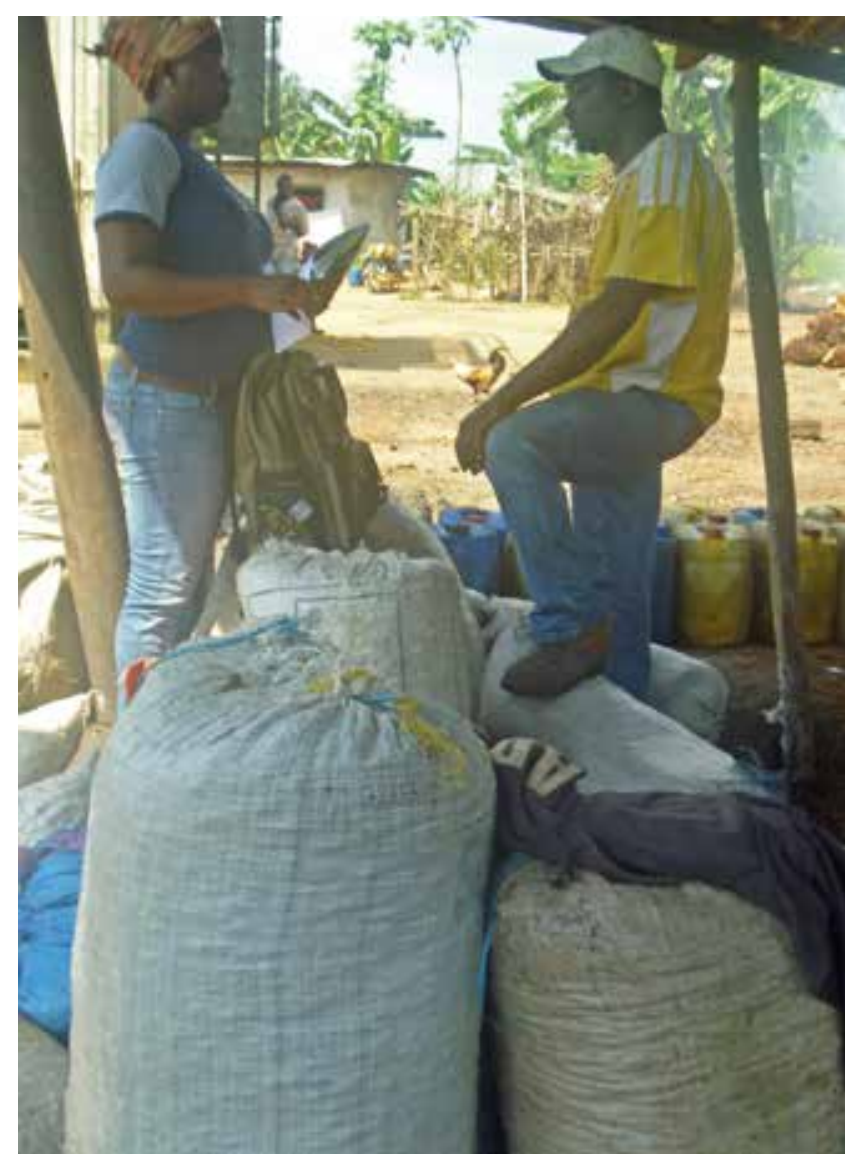

Picture 15. Loaded bags of palm kernel 


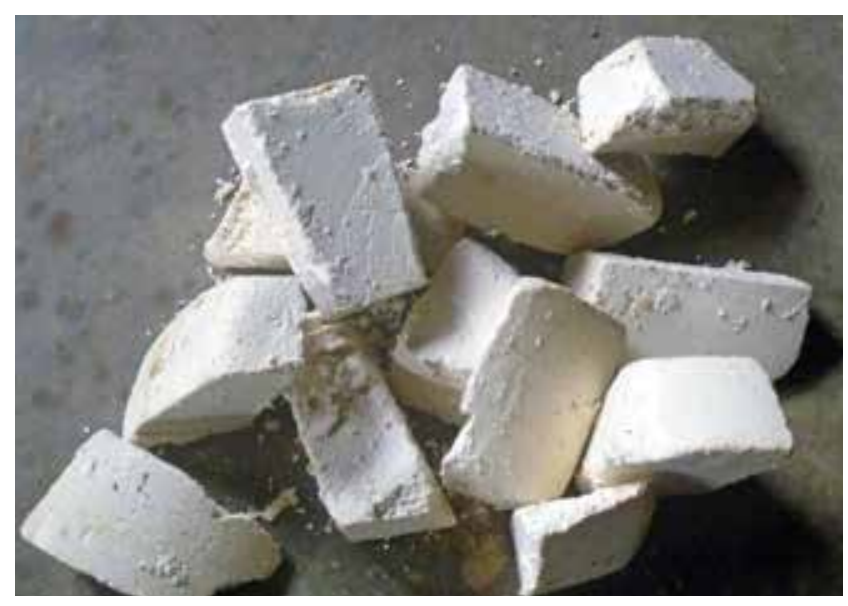

Picture 16. Local soap produced from palm oil

Soap making: Ingredients; $1 \mathrm{~kg}$ of caustic soda, 6 liters of water, 6 liters of oil (palm oil or sludge), 3 sachets of detergent (Saba, Madar, Bleu, etc.). The oil is warmed and kept to cool. The caustic soda is poured into the water and stirred with a stick until the content is well mixed. The detergents are added into the mixture and stirring continues until an even mixture is attained. The oil is then poured into the mixture and stirred in one direction (clockwise or anticlockwise) until a uniform texture is obtained. It is then poured in a wooden trough or any available container that can give it a good shape for solidification. When it cools and solidifies, it is cut into required sizes for eventual use. The profit margin could not be determined because the products were mainly for home use and the quantity sold was insignificant.

\subsection{Commercialization of CPO}

Field survey and market evaluation revealed that sales of CPO were in the form of retail, wholesale or both. All the producers were involved in the sale of CPO wherein they sell at wholesale at their palm oil mills or retail when there is a fraction that cannot make up the usual 20L or 120L. They receive orders to supply even before processing. Both men and women were involved in sale of CPO.

\section{Sale of CPO in domestic markets}

In domestic markets, $\mathrm{CPO}$ is sold in $1 \mathrm{~L}, 1.5 \mathrm{~L}, 5 \mathrm{~L}$ and $10 \mathrm{~L}$ containers for retail prices in the study areas. The wholesale quantity in Eseka and Dibombari was a 20L "bidon", while in Lobe it was in $30 \mathrm{~L}$ or $120 \mathrm{~L}$ "1-round jars".

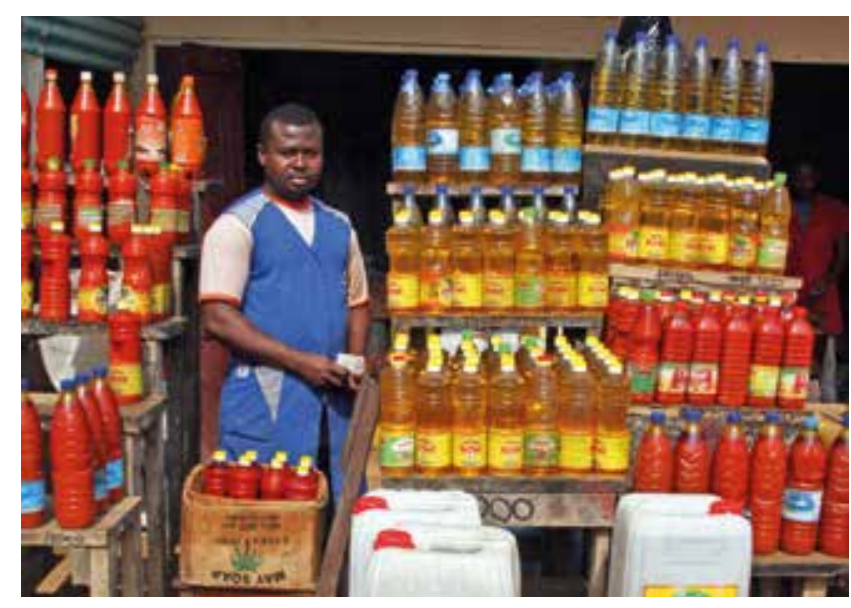

Picture 17. Palm oil retailer

Both men and women were involved in the commercialization of CPO. While the men buy from the mills and take to cities for wholesale, the women buy from mills and retail in local markets. Some women come from near and/or distant towns to buy. During peak season, there is high production and prices are reduced, while in low season the supply is reduced and prices are increased. There is a constant demand for CPO irrespective of the season or price. In Eseka and Dibombari areas, it was recorded that some persons store oil during peak season to be sold in September or December when prices are high. The income generated at this time of the year enables them to pay school fees for their children in September and/ or for the festive period in December.

Commercialization in the study area was categorized into four main groups:

- Processors/producers were mainly men and few women who were either POM owners or managers, $\mathrm{SH}$ or intermediaries.

- Primary buyers were those who buy CPO from producers and sell in local markets. It was observed to be practised by young women.

- Secondary buyers come from towns and buy from the local markets or producers, and later transport to town for sale. It was observed that this category was dominated by women and few men.

- Tertiary buyers purchase CPO in large quantities, usually tankers of at least $8,000 \mathrm{~L}$ to supply to companies for the production of refined palm oil or soap. They have their agents or contacts in the communities who buy and store the oil, and later contact them when the required quantity is ready. This category buys the different grades of oil at different prices. Those involved were mostly men. 


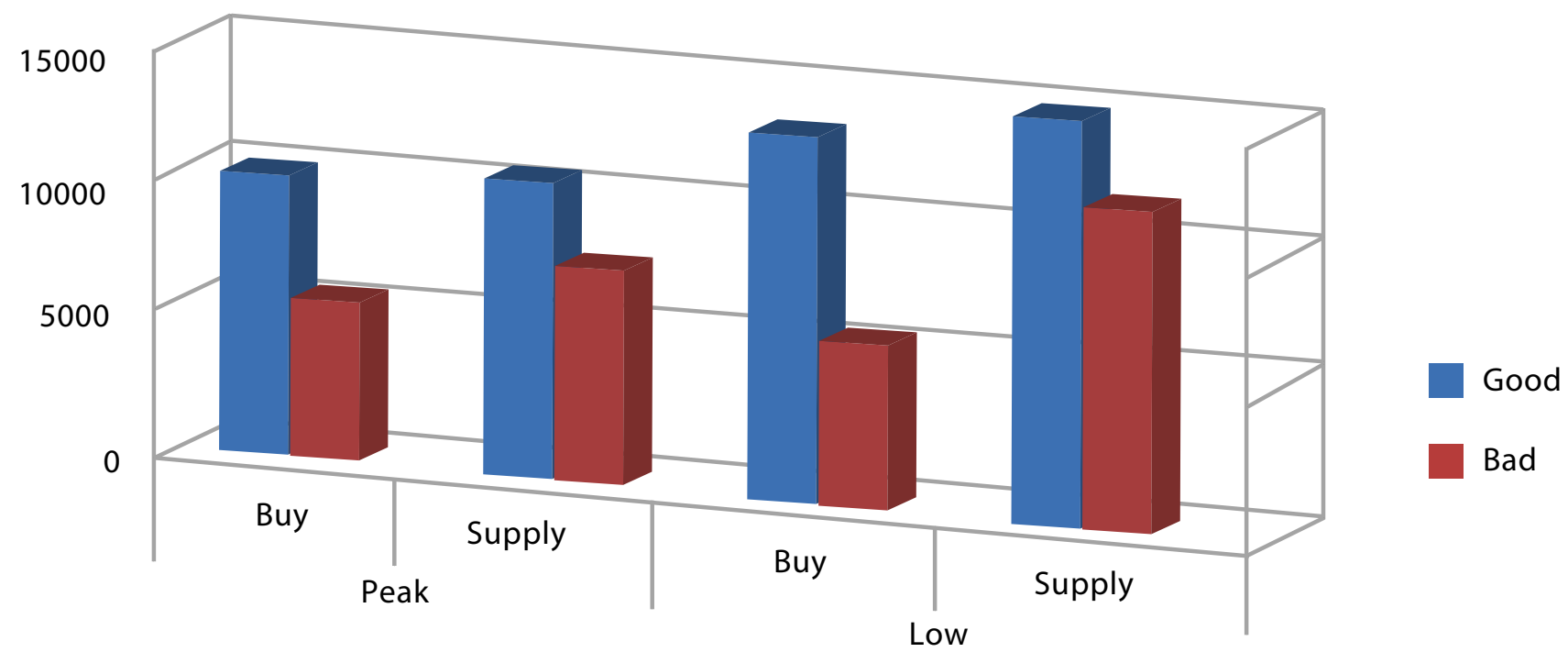

Figure 4. Average cost of first and second grades of oil supplied to tertiary buyers (in 20L)

\section{Description of market chains - artisanal, informal and industrial}

Due to high production of palm oil in these areas, buyers come from different parts of the country to purchase CPO in the palm oil mills and local markets. In Eseka, buyers generally come from Douala, Yaounde, Bafoussam, North and a local large-scale buyer from Badjob within the area. In Lobe, buyers generally come from Kumba, Douala, Bamenda, Dschang, Bafoussam and Nigeria when exchange is profitable. Some community members also buy and store oil to transport through the beach at Ekondo-Titi to Nigeria. In Dibombari, buyers come from Douala, Bamenda, Bafoussam, Dschang, Bangante, Mbouda, Foumban and Nkongsamba.

In all, buyers from Douala and Bafoussam go to all the production areas to buy red palm oil. The buyers from these different areas buy in large quantities (wholesale) and supply to other markets in retail or wholesale.

The tertiary buyers with tankers supply their oil to refineries and soap production companies such as Mayor and Azur among others for further processing into finished products.

\section{Fluctuation in prices of 1 liter of CPO in local markets over the years}

There is fluctuation in the prices of CPO over the years in different areas. Generally, the prices of sales of RPO are unstable. They vary with the season, accessibility to the mill, demand at local market and supply at the mills. This price in local markets is probably affected by the fact that palm oil producers do not have cooperatives (Ibitoye et al. 2011)

Table 7. Fluctuation in prices of CPO in local markets

\begin{tabular}{|c|c|c|c|c|c|c|c|c|c|c|}
\hline \multirow[t]{2}{*}{ Quantity } & \multirow[t]{2}{*}{ Unit (L) } & \multirow[t]{2}{*}{ Area } & \multicolumn{2}{|c|}{2009} & \multicolumn{2}{|c|}{2010} & \multicolumn{2}{|c|}{2011} & \multicolumn{2}{|c|}{2012} \\
\hline & & & $\mathbf{P}$ & L & $\mathbf{P}$ & L & P & L & P & $\mathrm{L}$ \\
\hline \multirow[t]{3}{*}{ Retail } & $1 \mathrm{~L}$ & Village & 400 & 450 & 400 & 450 & 450 & 600 & 400 & 700 \\
\hline & & Town & 400 & 500 & 400 & 600 & 500 & 700 & 600 & 800 \\
\hline & & City & 600 & 700 & 600 & 800 & 700 & 800 & 600 & 800 \\
\hline \multirow[t]{3}{*}{ Wholesale } & $20 \mathrm{~L}$ & Village & 9765 & 11279 & 10457 & 11700 & 10809 & 12271 & 9281 & 12468 \\
\hline & & Town & 9765 & 11279 & 10457 & 11700 & 10809 & 12271 & 9281 & 12468 \\
\hline & & City & 11265 & 13279 & 12457 & 13700 & 12809 & 14271 & 11281 & 14468 \\
\hline \multirow[t]{3}{*}{ Wholesale } & $120 \mathrm{~L}$ & Village & 44000 & 55000 & 58000 & 52000 & 55000 & 58000 & 58000 & 70000 \\
\hline & & Town & 54000 & 60000 & 58000 & 62000 & 65000 & 68000 & 65000 & 75000 \\
\hline & & City & 58000 & 65000 & 58000 & 62000 & 65000 & 70000 & 65000 & 75000 \\
\hline
\end{tabular}


Table 8. Contribution of income (from sales of CPO) to household livelihood in the study areas

\begin{tabular}{lccccc}
\hline \multirow{2}{*}{ Household livelihood } & \multicolumn{3}{c}{ Contribution of income to household livelihood } & \multicolumn{3}{c}{$\begin{array}{c}\text { Contribution of income in study } \\
\text { area }\end{array}$} \\
\cline { 2 - 4 } & Eseka & Lobe & Dibombari & \multicolumn{2}{c}{ Rank } \\
\cline { 2 - 5 } & Score & Score & Score & Average score & Rank \\
\hline Feeding & 44 & 46 & 47 & 46 & $1^{\text {st }}$ \\
Education & 38 & 42 & 37 & 39 & $2^{\text {nd }}$ \\
Health care & 39 & 40 & 32 & 33 & $3^{\text {rd }}$ \\
Savings & 4 & 15 & 15 & 11 & $4^{\text {th }}$ \\
Farm extension & 4 & 17 & 10 & 10 & $5^{\text {th }}$ \\
\hline
\end{tabular}

\subsection{Contribution of income to household livelihood}

Main source of income: After scoring and ranking the main sources of income of the respondents, milling (and sales of CPO) had the highest score and was ranked first in the study area, followed by farming of food and/or cash crops. The income generated from sales of CPO had significant contributions to household livelihood. The income was used in feeding, health care, education, farm extension, land acquisition, home constructions and management of palm oil farms and mill among others. The contribution to household livelihood was recorded by scoring, ranking and prioritizing the commitments as in the table below.

From Table 8, it can be deduced that feeding, education and health care were the priorities of over $90 \%$ of palm oil millers in the study area. Income generated from artisanal palm-oil milling enables the service providers to save. Savings, which take place mostly through "njangis" or tontines, were ranked fourth highest in the area

\subsection{The role of women}

Palm oil is very important as an income generator for women. Women are involved in buying FFBs from smallholders and processing the oil palm fruits into red palm oil. They take part in selection/sieving and loading, and hire labor for the tedious part of the milling process. They are in charge of selling the product in the local and even national market. They make more profit when they buy FFBs and process before selling the CPO than when they buy only CPO to sell (Ezealaji 2011). During the survey, apart from those who buy fruits and mill, two women were encountered in Eseka who own oil palm plantations (SHs) and two others in Lobe and Eseka respectively who have POMs.

\subsection{Constraints in small scale/artisanal milling of red palm oil}

The processing and marketing of red palm oil by artisanal POMs is a good initiative, but is subject to some difficulties.

Poor accessibility: The smallholders encounter a lot of difficulty in the transportation of FFBs from farms to the mills due to the poor road network in the study area. Accessibility to some farms is very poor. During the rainy season, roads are muddy and vehicles cannot ply the poorly developed farm-to-market roads. SHs incur additional expenses to hire labor in transporting FFBs to the mills. At times they devise a means wherein, after harvesting, the FFBs are kept in the farms, cut/chopped, stripped, sieved and loaded in bags. Workers are then hired to convey the loaded bags to the mills and commence with boiling. In Lobe area, buyers find it difficult to travel to the area to buy RPO, and if they manage to go there, they cannot find a vehicle to transport the palm oil. This tends to affect the prices during rainy season and processors are obliged to sell at prices offered by the few buyers.

Scarcity of labor: There is scarcity of labor especially during the peak season where almost every service provider in the area is actively involved in milling activity. POMs that do not have enough permanent workers available increase their bid on labor cost so as to attract more laborers. 
Accidents: Minor accidents do occur such as fire burns at the mills, hot oil or sludge spilling on a worker and the inhaling smoke by workers, all of which are detrimental to the health of the workers.

Negligence by workers to control fire for proper cooking of fruits at night can lead to fire outbreak in mills as the fire can easily extend to the dry planks usually used to construct the mills.

Unstable prices: The prices of RPO are unstable generally and in Eseka and Lobe areas, the state of the roads influences the prices of oil. During rainy season, there is a limited influx of buyers due to bad roads and the prices are reduced.

Inadequate know-how: Some of the processors have worked with the agro-industries and have a good knowledge of quality control methods in palm oil milling. More than $80 \%$ of the processors have not acquired any training in production of red palm oil. The inadequate know-how of the processors on the technical aspects of the business is a major constraint as reported in Ghana by Akangbe et al. (2011).

Inadequate capital: Some of the processing equipment is locally fabricated and requires regular repairs. Some mill owners may abandon their POMs to process fruits in another mill because of machine breakdown that they cannot afford to repair immediately.

Poor environmental management: The waste generated from milling activities such as empty fruit bunches, palm kernel and fiber, and effluent, are disposed around and no waste management scheme has been devised so far. The waste accumulates around the POMs and tends to reduce space/surface area for milling activities. The accumulated waste also pollutes the environment and serves as breeding grounds for mosquitoes.

Poor dynamics of smallholders' schemes: The smallholders process and sell the RPO individually without a common price at a particular season of production. They are not informed about improved sustainable processing methods, market strategies or market information systems.

\subsection{Oil storage}

Artisanal or small-scale mills simply fill/store the clarified oil in used plastic gallons of 20L "bidon" or $120 \mathrm{~L}$ (round jar) and store the drums at ambient temperature. Oil to be stored is steamed after processing to prevent coagulation and fractionation and the container is tightly covered to avoid possible airspace that can cause oxidation (FAO 2011). In Eseka, stored oil is usually placed on a plank because the cold from the floor can cause it to solidify quickly. Local perception believes that if the storage conditions are not followed, the stored oil may produce a bad odor and change the color from red to reddish-black. 


\section{Conclusion and recommendations}

Men were more involved in the transformation process than women, while women were more involved in the commercialization of palm oil. The role of women in the process was evident in sieving and loading during transformation and buying and selling the CPO in local markets and towns. Both family and hired labor were observed, although family labor was predominant in Eseka.

Commercialization of crude palm oil was observed and recorded to be a lucrative business in the study area. The millers sell the CPO in the village, while buyers come from different parts of the country to purchase in gallons of $20 \mathrm{~L}$ and $30 \mathrm{~L}$, as well as drums of $120 \mathrm{~L}$ and $200 \mathrm{~L}$. The prices vary with the season of production wherein it is low in peak season, increases through low season and is more expensive in "mid-peak".

Ameliorations in the transformation and sales of CPO depend on the variety of oil palm in the plantation, the type of machinery and operations, the labor force and the quality control methods put in place. Smallholders should come together and form a dynamic scheme that can enable them to improve on their oil palm plantations, processing equipment and methods, as well as on marketing strategies that provide access to market information systems of $\mathrm{CPO}$ in towns, cities and internationally.

Moreover, women should be given the opportunity to acquire land to establish oil palm plantations and palm oil mills. Women are very dynamic and their role in the transformation and commercialization of CPO will go a long way to improve on local livelihoods. Women groups should be trained on modern soap-making techniques using oil extracted from the mesocarp and endocarp of palm fruits.

Traditional milling methods served as a foundation to modern milling of palm oil. The incorporation of artisanal milling in policies of oil palm processing may serve as a rescue mission in the foreseeable future. This will generate more income and enable them to gain capital for diverse activities. 


\section{References}

Adegeye AJ. 1993. Farmers Support Team. Ceiba Ceigy Nig. Ltd. 10-14.

Affandi Yusoff MS, Cheong L-Z, Tan C-P, Long K and Lai O-M. 2010. Physicochemical, textural and viscoelastic properties of palm diacylglycerol bakery shortening during storage. J. Sci. Food Agric. 90: 2310-2317. doi: 10.1002/jsfa.4088.

Akangbe JA, Adesiji GB, Fakayode SB and Aderibigbe YO 2011. Towards palm oil selfsufficiency in Nigeria: Constraints and training needs nexus of palm oil extractors. Journal of Human Ecology 33(2):139-145.

Atinmo T and Bakre AT. 2003. Palm fruit in traditional African food culture. Asia Pacific Journal Clinical Nutrition 12(3):350-354.

Babatunde OO, Ige MT and Makanjuola GA. 2003. Effect of sterilization on fruit recovery in oil palm fruit processing. Journal of Agricultural Engineering Research 41(2):75-79.

Badmus GA. 1991. NIFOR Automated Small Scale Oil Palm Fruit Processing Equipment — its need, development and cost effectiveness: Proceedings 1991 International. Oil Palm Conference Chemistry and technology. In Basiron Y, et al, ed. Palm Oil Res. Inst. Malaysia, Kuala Lumpur [13.4.4], 20-31.

Bakoume C and Mahbob BA. 2006. Cameroon offers palm oil potential. Oils and fats

International 3:25-26.

Bakoumé C, Jannot C, Rafflegeau S, Ndigui B. and Weise S. 2002. Revue du secteur rural. Rapport palmier. Yaoundé: Integrated Research Application and Development (IRAD), Agricultural Research for Development (CIRAD), International Institute of Tropical Agriculture (IITA), Food and Agriculture Organization (FAO).

Carrere R. 2010. Oil palm in Africa: Past, present and future scenarios.: World Rainforest Movement Series on tree plantations 15. December, Montevideo.

Carrere R. 2006. Oil palm: The expansion of another destructive monoculture. Oil palm: From cosmetics to biodiesel. Colonization lives on. World Rainforest Movement, Montevideo.
Chaw MC and Ma AN. 2007. Processing of fresh palm fruits using microwaves. International Microwave Institute 40(3):165-173.

Corley RHV and Tinker PB. 2003. The Oil Palm. 4th Ed. John Wiley and sons, Hoboken, New Jersey, USA. 541 p.

Ezealaji NLO. 2011 Economics of Palm oil storage and marketing in Imo State, Nigeria. African Journal of Marketing Management, 3(10):253-260.

Hoyle D and Levang P. 2012. Oil palm development in Cameroon. Ad hoc Working Paper. World Wide Fund for Nature WWF, Institut de Recherche pour le Développement(IRD), Centre for International Forestry Research (CIFOR), Yaoundé, Cameroon.

Ibeckwe UC. 2008. Role of women in oil fruit processing and marketing in Imo State, Nigeria. Social Science 3(1):61-65.

Ibitoye OO, Akinsorotan AO, Meludu NT and Ibitoye BO. 2011. Factors affecting oil palm production in Ondo state of Nigeria. Journal of Agriculture and Social Research (JASR) 11(1).

Jannot C. 2000. Mémo sur le petit matériel de transformation des régimes de palme. CERNA, CIRAD, Freie Universität Berlin, SRPH

Ngando EGF, Mpondo MEA, Dikotto EEL and Koona P. 2011. Assessment of the quality of crude palm oil from smallholders in Cameroon. Journal of Stored Products and Postharvest Research, 2(3):52-58.

Owolarafe OK. Taiwo EA and Oko OO. 2008. Effect of processing conditions on yield and quality of hydraulically expressed palm oil. International Agro-Physics 22(4):349-352.

Poku K. 2002. Small-scale palm oil processing in Africa FAO Agricultural Services Bulletin. 148. Rome: Food and Agriculture Organization.

Rieger M. 2012. Oil Palm Taxonomy. www.fruitcrops.com.

Ross SA, Westerfield RW and Jordan BD 2001. Essentials of Corporate Finance. 3rd ed. McGraw-Hill Book; New York Company .

Tan C, Ghazali HM, Kuntom A, Tan C, and Ariffin AA 2009. Extraction and physiochemical properties of low free fatty acid properties crude palm oil. Food Chemistry 113: 645-650. 

CIFOR Working Papers contain preliminary or advance research results on tropical forest issues that need to be published in a timely manner to inform and promote discussion. This content has been internally reviewed but has not undergone external peer review.

This study was carried out in three major palm-oil producing areas in Cameroon with the aim of investigating the artisanal milling and commercialization of red palm oil. Structured and semi-structured questionnaires were administered; focus group discussions and participatory observation were applied to obtain required information. Those involved were identified and the service providers ranged from mill owners or managers to smallholders and intermediaries, some of which were involved in two or three of the services. All told, $83 \%$ of those involved were men, and the women represented $17 \%$ of the service providers. Six different types of processing equipment were identified in the production areas and it was revealed that semi-automated press and combined motorized hydraulic digester and press system (digester screw press) were the most efficient. After harvesting of fresh fruit bunches (FFBs), the major operations were: chopping or cutting, stripping, selecting and sieving, loading to drums for boiling, off-loading to the digester or press for crushing and/or pressing, and clarifying of palm oil. Family labor, hired labor or both, contributed greatly to the success of the milling operations. Family labor was not paid, but motivations were given to family members, while hired labor was paid per activity. The average cost of labor per ton of FFB in the study area was 8,812 FCFA for both peak and low seasons. The average net return in the processing and marketing of 1 ton of FFB was 32,207 FCFA in peak season and 46,556 FCFA in low season. This income-generating activity was ranked as the first main source of income in the study area and has valuable contributions in household livelihood. The production of palm kernel oil and local soap was also recorded in the area, but this was mainly for home use and not for sale. Poor accessibility and unstable prices were the main constraints in the production process. While the men were dominant in processing, women were dominant in the commercialization of RPO. Artisanal palm-oil milling is a lucrative business in the area and will go a long way to alleviate poverty if the smallholders could come together and form a dynamic scheme. Forests, Trees and use of forests, agroforestry and tree genetic resources across the landscape from forests to farms. Agroforestry 